\title{
Credit Reform and the States: The Vital Role of Attorneys General After Dodd-Frank
}

\author{
Mark Totten ${ }^{*}$
}

\begin{abstract}
Congress employed multiple strategies in the wake of the Great Recession to provide greater protections for consumers in the financial marketplace. One strategy aimed at agency design and resulted in creation of the Consumer Financial Protection Bureau. Another strategy created new substantive prohibitions and corresponding mulemaking powers. A third strategy channeled the forces of federalism, placing a limit on agency preemption and empowering state attorneys general to enforce federal law. Scholars have focused on the first two strategies, plus the new constraints on preemption, but so far have not given sustained attention to the role of states as co-enforcers of federal consumer financial protection law. This Article seeks to fill that void, focusing on implementation and charting $a$ path for normative assessment.
\end{abstract}

I begin by placing this dualenforcement scheme within the context of recent history and the evolving infrastructure for consumer financial protection in the United States. I then consider several interpretive issues to account for the substantive, procedural, and remedial powers Congress placed in the hands of state attomeys general. Recognizing that the success of this concurrentenforcement regime will depend in part on early coordination, I next identify several implementation priorities necessary to create a scheme that is both effective and efficient. Finally, I identify key questions and offer preliminary observations toward a normative assessment of this scheme and its implications both for consumer finance and American federalism.

* Associate Professor of Law, Michigan State University College of Law. Thanks to Prentiss Cox, Jennifer Epperson, Glen Staszewski, James Sullivan, Jim Tierney, Art Wilmarth, workshop participants at the University of Maryland Francis King Carey School of Law Junior Faculty Exchange, and my colleagues who participated in the Michigan State University College of Law Summer Workshop Series. In addition, I am grateful for several senior officials in state and federal government who agreed to interviews and provided critical insight on interpretive and implementation issues. 
INTRODUCTION

I. INFRASTRUCTURE.

A. THE STRUCTURE OF CONSUMER FINANCIAL PROTECTION PRE-20 IO.. 119

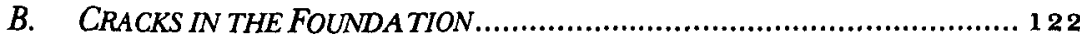

C. THE DODD-FRANK RECONSTRUCTION........................................ 125

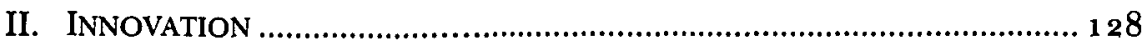

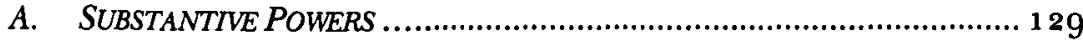

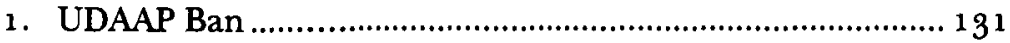

2. Other Federal Consumer Financial Protection Laws .......... $13^{6}$

3. New Substantive Limits on Mortgage Terms ....................... 141

B. PROCEDURAL AND REMEDIAL POWERS.......................................... 142

1. Investigation ........................................................... 142

2. Forum Selection and Multi-State Litigation...................... 145

3. Outside Counsel ................................................................. 149

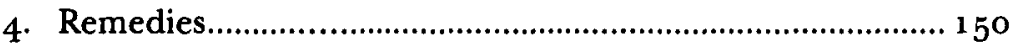

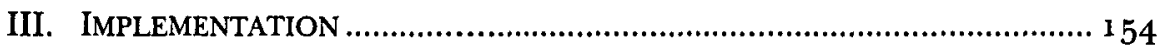

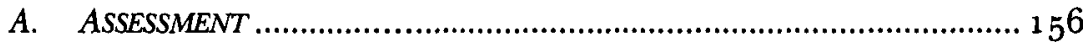

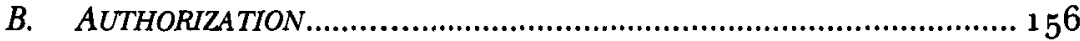

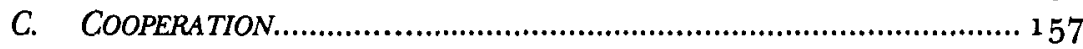

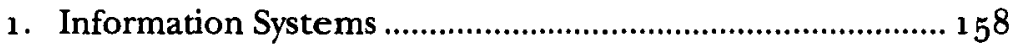

2. Investigation and Enforcement Actions ............................ 161

3. Rulemaking................................................................. $16_{5}$

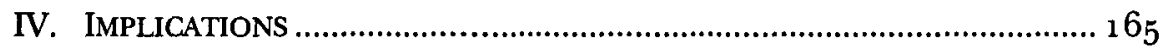

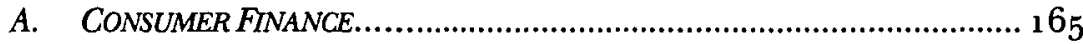

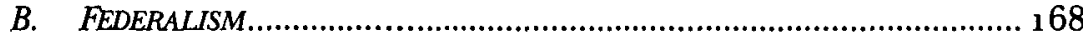

1. Recurrent Claims............................................................... 168

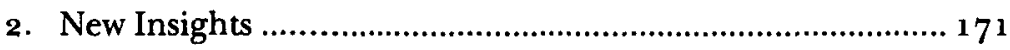

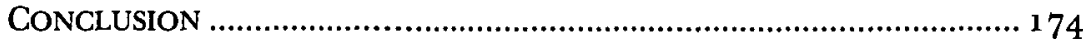




\section{INTRODUCTION}

States are once again poised to play a vital role protecting consumers in the financial marketplace. For decades, state common law was the only means of redress. As states began to craft safeguards for the law books, so did Congress. At times the states were cooperators. At other times they were competitors. Beginning in the mid-19gos, and over the next decade, however, federal banking agencies preempted state actions against federally chartered depositories and their subsidiaries. In the shadow of federal inaction, the states were often helpless to stop the most egregious abuses leading to the 2008 economic crisis. Congress's primary response to the Great Recession was the Dodd-Frank Wall Street Reform and Consumer Protection Act of 2010 (Dodd-Frank Act or Act).' Among other reforms, the Act secures important powers for the states.

The reach of the Dodd-Frank Act is broad. It covers not only financial markets and the institutions that participate in those markets, but also individual consumer products such as mortgages, credit cards, student loans, gift cards, and personal banking. From Wall Street to Main Street, the legislation re-defines the landscape. In particular, the Act employs three strategies to strengthen consumer financial protection. First, it addresses root failures through institutional design. Most important, Congress created one agency - the new Consumer Financial Protection Bureau ("CFPB")that possesses both the authority and motivation to protect consumers." Second, the Act creates new substantive rules that shape how businesses and consumers participate in the market. And third, Congress harnessed the forces of federalism by placing limits on agency preemption and empowering states to enforce federal law.

To this point in time, attention has focused on the first two strategies and the limits on agency preemption.s While scholars have recently begun

1. Dodd-Frank Wall Street Reform and Consumer Protection Act, Pub. L. No. 111-203, 124 Stat. 1376 (2010).

2. I borrow the language of "authority and motivation" from Warren and Bar-Gill. See Oren Bar-Gill \& Elizabeth Warren, Making Credit Safer, 157 U. PA. L. REV. 1, 85 (2008). By empowering one agency to protect consumers, Congress aimed to overcome past hindrances: motivated administrative actors that lacked the legal authority to protect consumers, or authorized actors that lacked the motivation to act because of conflicting incentives.

3. See, e.g., KathleEn C. ENGel \& PATRICia A. MCCOY, The SubPrime Virus: ReCKless CREDIT, REgulatory FAILURE, AND NeXT STEPS (2011); Bar-Gill \& Warren, supra note 2; Kathleen C. Engel \& Patricia A. McCoy, Federal Preemption and Consumer Financial Protection: Past and Future, 3 BANkING \& FIN. SERVICES POL'Y REP. 25 (2012); Patricia A. McCoy et al., Systemic Risk Through Securitization: The Result of Deregulation and Regulatory Failure, $4^{1}$ CoNN. L. REV. 1327 (2009); Catherine M. Sharkey, Inside Agency Preemption, 110 MICH. L. REV. 521, 553-56 (2012); Arthur E. Wilmarth, Jr., The Dodd-Frank Act's Expansion of State Authority to Protect Consumers of Financial Services, 36 J. CoRP. L. 893, 897-919 (2011) (raising the role of states as co-enforcers, but focusing on preemption). 
to examine the general contours of concurrent-enforcement regimes, 4 no one has given sustained attention to the role of states and state attorneys general ("SAGs") as co-enforcers of federal law under the Dodd-Frank Act. Addressing this gap is critical if only because the Act creates one of the largest dual-enforcement regimes ever, but also because the states play a vital role in reforming the system. Concurrent-enforcement powers are the necessary complement to the strategies of institutional design and statutory rulemaking. I attempt to fill this void in the literature on dual-enforcement powers by addressing key interpretive issues and implementation priorities, while also considering the implications of this reform for consumer finance and the role of concurrent enforcement in American federalism. 5

In Part I, "Infrastructure," I sketch the system of consumer financial protection in the United States and its recent history. This brief account traces the role of the states in consumer financial protection to provide context for the reforms Congress passed in 2010 . In Part II, "Innovation," I describe the substantive, procedural, and remedial powers Congress placed in the hands of state attorneys general, addressing critical interpretive issues concerning the scope of these powers. The gap between a statutory grant of power and an effective and efficient concurrent-enforcement regime, however, is potentially wide. While federal agencies typically carry out a congressional mandate, in the case of state enforcement, implementation depends on the independent decisions of fifty state attorneys general, who are very different actors than the expert administrators who populate the executive branch. How states exercise these powers, and the systems in place to support state enforcement, are critical in determining the success or failure of reform. In Part III, "Implementation," I therefore identify several system-building priorities. Lastly, in Part IV, "Implications," I identify key questions and offer a few preliminary observations toward a normative assessment of this scheme and its implications both for consumer finance and American federalism.

4. See generally Rachel E. Barkow, Insulating Agencies: Avoiding Capture Through Institutional Design, 89 TEX. L. REV. 15 (2010); Margaret H. Lemos, State Enforcement of Federal Law, 86 N.Y.U. L. REV. 698 (2011); Amanda M. Rose, State Enforcement of National Policy: A Contextual Approach (with Evidence from the Securities Realm), 97 U. MINN. L. REV. 1343 (2013); Amy Widman, Advancing Federalism Concerns in Administrative Law Through a Revitalization of State Enforcement Powers: A Case Study of the Consumer Product Safety and Improvement Act of 20o8, 29 YAlE L. \& POL'Y REv. 165 (2010); Amy Widman \& Prentiss Cox, State Attorneys General's Use of Concurrent Public Enforcement Authority in Federal Consumer Protection Laws, 33 CARDOZO L. REV. 53 (201 1 ).

5. The Dodd-Frank concurrent-enforcement scheme bears some resemblance to a concurrent regulatory regime insofar as the Act also constrains the power of federal agencies to preempt state consumer financial protection laws and thereby opens a broader space for state regulation than what the states experienced in the last two decades. 


\section{INFRASTRUCTURE}

The modern legal framework for consumer financial protection in the United States has evolved over the past century, most recently through the Dodd-Frank Act and especially Title X of that Act. I briefly describe this evolution as prelude to examining the innovations Congress introduced by giving states concurrent-enforcement powers.

\section{A. The Structure of Consumer FInANCIAL Protection Pre-2o Io}

Consumer financial protection in the United States is a patchwork of state and federal law. ${ }^{6}$ The earliest means of redress arose out of state common law as tort and contract remedies, such as claims of breach of contract, unconscionability, fraud, and fraudulent misrepresentation. 7 The common law, however, proved inadequate for several reasons. First, contractual claims required privity between buyer and seller, but increasing social mobility often made this requirement difficult to establish. ${ }^{8}$ Second, common law judges reserved the unconscionability doctrine for only the most egregious cases.9 Next, tort claims required the plaintiff to leap a difficult mens rea hurdle, by requiring proof that the seller had intent to deceive. ${ }^{10}$ Finally, common law claims in tort required an actual injury, a requirement which precluded prospective relief." These and other shortcomings spurred the development of statutory protections.

The most important early reform was the Federal Trade Commission Act ("FTCA") of 1914, which created the Federal Trade Commission ("FTC") and which remains the centerpiece of modern consumer protection law at the federal level. ${ }^{2}$ As originally passed, this law had two

6. See, e.g., Mark E. Budnitz, The Federalization and Privatization of Public Consumer Protection Law in the United States: Their Effect on Litigation and Enforcement, 24 GA. ST. U. L. REV. 663,664 (2008) ("There is no uniformity and no consistency among the various consumer protection laws and how they are enforced because there is no national consensus on what laws are necessary to protect consumers and who should enforce those laws."); Edward M. Crane et al., U.S. Consumer Protection Law: A Federalist Patchwork, 78 DEF. CouNS. J. 305, 305 (201 1) ("Unlike many foreign jurisdictions, the United States lacks a singular, comprehensive consumer protection code. Consumer protection law in the United States is instead a patchwork of federal and state laws.").

7. See Henry N. Butler \& Joshua D. Wright, Are State Consumer Protection Acts Really LittleFTC Acts?, 63 FLA. L. REV. 163, 168-69 (2011); Victor E. Schwartz \& Cary Silverman, CommonSense Construction of Consumer Protection Acts, 54 U. KAN. L. REV. 1, 6-7 (2005); Joshua D. Wright, The Antitrust/Consumer Protection Paradox: Two Policies at War with Each Other, 121 YALE L.J. 2216 , 2226-27 (2012).

8. Butler \& Wright, supra note 7 , at 169 .

9. Bar-Gill \& Warren, supra note 2 , at 71 .

10. Schwartz \& Silverman, supra note 7 , at 6.

11. Id. at 7 .

12. Federal Trade Commission Act (FTCA), Pub. L. No. 63-203, 38 Stat. 717 (1914) (codified as amended at 15 U.S.C. $\$ \S 44^{1-5^{8}}(2006)$ ). 
limitations. First, it only prohibited "unfair methods of competition." 13 This language focused the agency on antitrust violations. The Supreme Court reinforced this narrow focus, holding in 1931 that the agency lacked authority to issue a cease-and-desist order with regard to false advertising that caused harm to consumers but did not present a competitive injury. ${ }^{14}$ In response, Congress amended the FTCA to also prohibit "unfair or deceptive acts or practices" ("UDAP"), a broad standard giving the agency greater flexibility to protect consumers. ${ }^{15}$ In 1975 , Congress clarified that the agency not only had power to bring individual actions, but also to promulgate rules enforcing this prohibition. ${ }^{16}$

Second, the FTCA as passed and amended has never allowed the FTC to enforce its powers against banks, and for several decades considerable doubt persisted as to whether any agency could enforce the Act's UDAP ban against federal depositories. ${ }^{17}$ In the same 1975 Act recognizing the FTC's rulemaking power, however, Congress charged the various banking regulators to take complaints for alleged UDAP violations and charged the Federal Reserve Board ("Fed") to promulgate rules under the prohibition. ${ }^{18}$ Moreover, Congress required the Fed to "promulgate substantially similar regulations" whenever the FTC prescribed a rule under section $5^{\cdot 19}$ Congress placed enforcement of the UDAP regulations in the hands of the federal banking agencies. ${ }^{20}$ Overall, the federal UDAP ban coupled with rulemaking power is a potent and flexible tool: an administrative law approach that escapes many of the weaknesses inherent in common law remedies and allows industry-wide regulation rather than just case-by-case enforcement.

Beginning in the 1960 , the states increased efforts to protect consumers. ${ }^{21}$ The 1975 reforms under the FTC Improvement Act were in part motivated by a growing concern that the FTC was the victim of

13. Id. at 38 Stat. at 719 .

14. FTC v. Raladam, Co., 283 U.S. 643, 653 (1931).

15. Wheeler-Lea Act of 1938, Pub. L. No. 75-447, § 3, 52 Stat. 111,111 (codified as amended at 15 U.S.C. $\$ 45$ (a) (2012)).

16. The FTC began issuing Trade Regulation Rules ("TRRs") in 1962, allowing it to regulate an entire industry rather than just a particular entity. Industry challenged the agency's authority for rulemaking in National Petroleum Refiners Ass'n v. FTC, $4^{82}$ F.2d 672 (D.C. Cir. 1973), which held that the agency possessed such power. Congress subsequently codified this holding. See FTC Improvement Act of 1975, Pub. L. No. 93-637, § 202 (a), 88 Stat. $2183,2193-$ 98 (1975) (codified as amended at 15 U.S.C. $\$ 57$ a (2012)).

17. See Julie L. Williams \& Michael S. Bylsma, On the Same Page: Federal Banking Agency Enforcement of the FTC Act to Address Unfair and Deceptive Practices by Banks, $5^{8}$ BUS. LAW. 1243 , 1243-49 (2003).

18. FTC Improvement Act $\$ 202$.

19. Id.

20. Id.

21. See generally Budnitz, supra note 6, at 674-77; Butler \& Wright, supra note 7, at 167-73; Schwartz \& Silverman, supra note 7 , at $15-32$. 
regulatory capture. ${ }^{22}$ A growing consumer movement, the limitations of common law remedies, and a concern that the substantive protections offered in federal law may not have been sufficient, all fueled the adoption of state-level consumer protection acts.23 By 1981 every state had adopted such legislation, many modeled after the federal UDAP ban and sometimes referred to as "little-FTC Acts." "24

Although the level of protection provided in these state laws varied, they had several advantages over their federal counterpart from the perspective of consumer advocates. ${ }^{25}$ Most important, they included a private right of action and recoupment of attorney's fees, allowing consumers to seek redress in the courts rather than depending on action by the FTC. In addition, they often permitted a broader range of remedies, including actual, statutory, and even treble or punitive damages, and often allowed for class actions to provide redress for small but widespread injuries.

In addition to the federal UDAP ban and similar state consumer protection acts, both Congress and the states have passed laws targeting specific issues. The earliest federal law designed to protect consumers in the financial marketplace was the Truth in Lending Act ("TILA"), passed in $1968 .{ }^{26}$ TILA adopts a disclosure strategy and requires creditors to state the terms and costs of credit, allowing product comparison and cost calculation. ${ }^{27}$ In addition, Congress has regulated other areas including credit reporting, ${ }^{28}$ credit billing, ${ }^{29}$ debt collection, ${ }^{30}$ credit cards, $3^{1}$ credit

22. See Butler \& Wright, supra note 7 , at $167-68$.

23. Id. at $167-69$.

24. Id. at 169; DeE Prigden \& RiChard M. Alderman, Consumer Protection ANd tHE LAW Appendix $3^{\mathrm{A}}$ (2011) (listing state consumer protection statutes, including date of enactment and citation).

25. See generally Budnitz, supra note 6, at 674-77; Butler \& Wright, supra note 7 , at $167-73$; Schwartz \& Silverman, supra note 7, at 15-32.

26. Truth in Lending Act (TILA), Pub. L. No. 90-321, 82 Stat. 146 (1968) (codified as amended at 15 U.S.C. $\$ \$ 1601-1667 \mathrm{f}(2006)$ ). TILA is Title I within a larger legislative package known as the Consumer Credit Protection Act (CCPA), Pub. L. No. go-321, 82 Stat. 146 (1968). Congress has amended TILA multiple times. See Crane et al., supra note 6, at 320-21.

27. TILA $\$ 102(b)$ (codified as amended at 15 U.S.C. $\$ 1601$ (a) (2012)) ("It is the purpose of this title to assure a meaningful disclosure of credit terms so that the consumer will be able to compare more readily the various credit terms available to him and avoid the uninformed use of credit, and to protect the consumer against inaccurate and unfair credit billing and credit card practices.").

28. See, e.g., Fair Credit Reporting Act (FCRA), Pub. L. No. 91-508, 84 Stat. $113^{6}$ (197o)

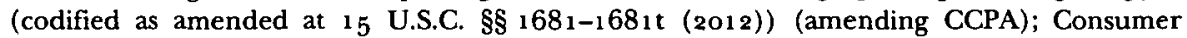
Credit Reporting Reform Act (CCRRA), Pub. L. No. 104-208, 110 Stat. 3oog (1996) (codified as amended in scattered sections of 15 U.S.C) (amending FCRA); Fair and Accurate Credit Transactions Act (FACTA) of 2003, Pub. L. No. 108-1 59, 117 Stat. $195^{2}$ (codified as amended at 15 U.S.C. $\$ \S 1681-1681 y$ (2012)) (amending FCRA).

29. See, e.g., Fair Credit Billing Act (FCBA), Pub. L. No. 93-495, 88 Stat. $115^{1}$ (1975) (codified as amended in 15 U.S.C. $\$ 1666$ (2012)) (amending TILA). 
repair,,$^{2}$ access to credit,33 electronic transfer of funds, 34 and real estate transactions. ${ }^{35}$ Congress dispersed enforcement powers under these statutes. For example, prior to the Dodd-Frank Act, the Fed had rulemaking powers under TILA ${ }^{3}$ and nine federal agencies held enforcement powers, with FTC in the lead.37 Similarly, many states also adopted laws targeting specific threats, like predatory lending..$^{8}$

\section{B. CRACKS IN THE FOUNDATION}

Although some observers had already discerned trouble in the structure of consumer financial protection, the recession that began in 2008 shed a bright light on cracks in the foundation. 39 The fissures were at least two: federal regulators failing to exercise their rulemaking and enforcement powers, and then preventing states from enforcing state laws.

Inaction at the Federal Reserve Board during the critical years leading up to the crisis is a telling example. The Fed had authority to issues rules and stop abuses in the mortgage lending market which fueled the crisis,

3o. See, e.g., Fair Debt Collection Practice Act (FDCPA), Pub. L. No. 95-109, 91 Stat. 874 (1977) (codified as amended at 15 U.S.C. $\$ \S 1692-16920$ (2006)) (amending CCPA).

31. See, e.g., Fair Credit and Charge Card Disclosure Act (FCCCA) of 1988, Pub. L. No. $100-583,102$ Stat. 2960 (codified as amended in scattered sections of 15 U.S.C.) (amending TILA); Credit Card Accountability Responsibility and Disclosure Act of 2009 (Credit CARD Act), Pub. L. No. 111-24, 123 Stat. 1734) (codified as amended in scattered sections of 15 U.S.C.).

32. See, e.g., Credit Repair Organizations Act (CROA), Pub. L. No. 104-208, 110 Stat. 3009 (1996) (codified at 15 U.S.C. $\$ \S 1679-1679$ i (2012)).

33. See, e.g., Equal Credit Opportunity Act (ECOA), Pub. L. No. 93-495, 88 Stat. 1521

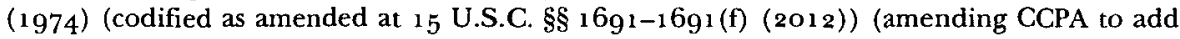
Title VII).

34. See, e.g., Electronic Fund Transfer Act (EFTA), Pub. L. No. 95-630, 92 Stat. $37^{28}$ (1978) (codified as amended at 15 U.S.C. $\$ 1693$ ) (amending CCPA to add Title IX).

35. See, e.g., Real Estate Settlement Procedures Act (RESPA), Pub. L. No. 93-533, 88 Stat. 1724 (1974) (codified as amended at 12 U.S.C. $\$ \$ 2601-2617$ (2012)).

36. TILA, Pub. L. No. 90-321, $\$ 105,82$ Stat. 146 (1968) (codified as amended at 15 U.S.C. $\$ \S 1601-1667 \mathrm{f}(2006))$.

37. TILA $\$ 108$.

38. See Baher Azmy, Squaring the Predatory Lending Circle, 57 FLA. L. Rev. 295, 361-78 (2005) (reviewing the different state responses, starting with North Carolina in 1999); see also Budnitz, supra note 6, at 676 ("In addition to UDAP statutes, states have enacted laws regulating many specific types of transactions including retail installment sales contracts and motor vehicle sales financing. States also regulate home solicitation sales and usury. While these statutes provide consumers another layer of protection besides the UDAP laws, they have a very narrow scope." (citations omitted)).

39. For assessments of systemic failure prior to the Dodd-Frank Act, see ENGEL \& MCCOY, supra note 3; Bar-Gill \& Warren, supra note 2, at 79-97; Prentiss Cox, The Importance of Deceptive Practice Enforcement in Financial Institution Regulation, 30 PACE L. REV. 279, 297-300 (2009); McCoy et al., supra note 3 ; Wilmarth, supra note 3 , at $897-919$. 
especially in the market for subprime and Alt-A mortgages. $4^{\circ}$ As mentioned earlier, the Fed had rulemaking power to prevent unfair and deceptive practices under the FTCA.4' This power, however, was originally limited to banks and did not reach nonbank lenders even though abuses by such lenders were rampant. In the Home Ownership and Equity Protection Act of 1994 ("HOEPA"), however, Congress gave the Fed power to issue rules preventing unfair and deceptive acts or practices committed by any mortgage originator. $4^{2}$ Despite awareness of the risky lending practices in these markets throughout the decade, it was not until the crisis erupted and with a change in the chairmanship that the Fed finally exercised its UDAP powers in July 20o8.43 The new rule had limited reach and by then the subprime lending market had shut down.44 Other federal regulators demonstrated the same failure to exercise their rulemaking powers, and also to exercise their supervisory and enforcement powers to stop toxic lending practices. 45

The second crack in the foundation of consumer financial protection was the dramatic move by federal agencies to preempt state laws aimed at the abusive lending practices federal regulators refused to address. $4^{6}$ States had been at the forefront of consumer protection in the banking field for

40. These two types of loans are loosely defined. "Subprime" loans are targeted at borrowers who have poor credit history and lack the savings to make a down payment. "Alt-A" loans ("Alternative A-paper," where "A-paper" loans are prime loans) are marketed to persons who do not qualify for prime lending because they pose some level of risk, although less risk than subprime borrowers. Recipients of Alt-A loans may have minor credit issues or otherwise are unable or unwilling to document their assets or income. These forms of nonprime lending spiked in the years leading up to the economic crisis and were a major cause of the recession. In 1995 subprime lending accounted for $\$ 6_{5}$ billion in loans; by 2006 it accounted for $\$ 600$ billion. Likewise, Alt-A loans went from $\$ 60$ billion in 2001 to $\$ 400$ billion in 2006. See Arthur E. Wilmarth, Jr., The Dark Side of Universal Banking: Financial Conglomerates and the Origins of the Subprime Financial Crisis, $4^{1}$ CONN. L. REV. 963, $1015^{-16}$ (2009).

41. See supra notes $15^{-16}$ and accompanying text.

42. Riegle Community Development and Regulatory Improvement Act of 1994, Pub. L. No. $103-325, \$ \S 15^{1-1} 5^{8,108}$ Stat. $2190,2190-98$ (codified as amended at 15 U.S.C.). See also ENGEL \& MCCOY, supra note 3, at 194-96; Wilmarth, supra note 3, at 898-9oo.

43. See ENGEL \& MCCOY, supra note 3, at 195-96; Wilmarth, supra note 3 , at 899 .

44. See Wilmarth, supra note 3 , at 899 .

45. The Federal Reserve Board failed to regulate nonbank mortgage lenders that were subsidiaries of bank holding companies, over which the Fed had authority. See Wilmarth, supra note 3, at 9oo-o1. The Office of Thrift Supervision ("OTS"), which regulated federally chartered or insured savings and loans, and the Office of the Comptroller of the Currency, which regulated federally chartered banks, demonstrated the same inaction. See Keith R. Fisher, Toward a Basal Tenth Amendment: A Riposte to National Bank Preemption of State Consumer Protection Laws, 29 HARV. J.L. \& PUB. POL'Y 981, 991-94. (2006); McCoy et al, supra note 3, at 151-56; Wilmarth, supra note 3 , at $903-06$.

46. For general accounts of federal agency preemption leading up to the economic crisis, see ENGEL \& MCCOY, supra note 3, at 157-59; Bar-Gill \& Warren, supra note 2, at 79-83; McCoy

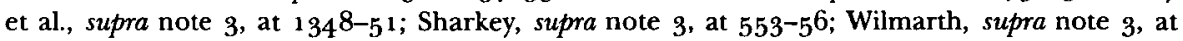
910-15. 
over a century, including against nationally chartered banks. Moreover, in the absence of federal action, and eyeing the ever-growing threat, states tried to act both by passing anti-predatory lending legislation and by bringing enforcement actions, such as the multistate actions against Ameriquest and Household International.47 In many cases, however, they were blocked by aggressive federal agencies that aimed to insulate the institutions they chartered from state consumer protections.

In the early 1990 , all mortgage lenders had to comply with state laws. Beginning in 1996, and over the next decade, however, the Office of Thrift Supervision ("OTS") and the Office of Comptroller of the Currency ("OCC") sought to free federally chartered depositories from state regulation. In 1996 the OTS issued a regulation that declared the agency occupied the entire field for lending regulation over federal savings associations, $4^{8}$ and then in 1996 applied the same relief to subsidiaries of these institutions.49 The OCC followed the same path, preempting most state laws in 2004 that previously applied to national banks and their subsidiaries, ${ }^{\circ}$ and then barring enforcement actions by states against these institutions, even with respect to non-preempted state laws. $5^{1}$ The twin strategies of preemption and inaction especially aggrieved the states.5 $\mathbf{5}^{2}$

These cracks in the foundation of consumer financial protection stemmed from at least two design flaws in the federal regulatory structure: conflicting missions and misaligned incentives. The primary mission of the banking agencies is to protect the "safety and soundness" of the institutions they oversee.53 Although a broad interpretation of this mission might

47. See supra note 38; Wilmarth, supra note 3, at 9o9-10; Kirstin Downey, Mortgage Lender Settles Lawsuit, WASH. POST (Jan. 24, 2006), http://www.washingtonpost.com/wp$\mathrm{dyn} /$ content/article/2006/o1/23/AR2oo612301523.html.

48. Lending and Investment, 61 Fed. Reg. 50,951 (Sept. 30, 1996) (codified in scattered sections of 12 C.F.R.).

49. Subsidiaries and Equity Investments, 61 Fed. Reg. 66,561 (Dec. 18, 1996) (codified in scattered sections of 12 C.F.R.).

5o. Bank Activities and Operations; Real Estate Lending and Appraisals, 69 Fed. Reg. 1904 (Jan. 13, 2004).

51. Bank Activities and Operations, 69 Fed. Reg. 1895 (Jan. 13, 2004).

52. See Letter from Nat'l Ass'n of Attorneys Gen., to Mr. John Walsh, Acting Comptroller, Office of the Comptroller of the Currency (June 27, 2011), available at http://www.naag.org/naag-responds-to-occ-proposed-financial-reform-regulations.php (“Over the last decade, state Attorneys General have vigorously opposed the OCC's aggressive campaign to preempt state consumer protection laws. In 2003 , all 50 state Attorneys General filed comments on the OCC's proposed preemption rules. Those rules attempted to preempt consumer protection laws that the states had enforced for years in the financial marketplace, including against national banks.").

53. See, e.g., Federal Deposit Insurance Corporation Improvement Act, Pub. L. No. 102$242, \S 132,105$ Stat. $2236,2267-70$ (1991) (codified as amended at 12 U.S.C. $\$ 1831$ p-1 (2012)) (requiring federal banking agencies, for all insured depository institutions, to prescribe safety and soundness standards concerning operational and managerial standards; asset quality, earnings, and stock valuation standards; and compensation standards). The 
include consumer financial protection, banking agencies concerned with safety and soundness focus primarily on the banks' stability and profitability.54 The commitment to consumer protection was, at best, a distant second; more often, the agencies perceived consumer protection to conflict with their primary mission.

The consequences of this conflict for consumer protection were heightened by a second design flaw: misaligned incentives. Under the "dual" banking system in the United States, financial institutions can organize as banks, thrifts, or credit unions, under state or federal charters. 55 Moreover, institutions often have mobility and can move between regulators based on the favorability of the corresponding regulatory regime. Both the OCC and the OTS received funding almost exclusively based on assessments paid by the institutions they regulated. $5^{6}$ This arrangement created a classic race to the bottom, where the banking agencies sought to increase market share by minimizing consumer protections. 57

\section{THE DODD-FRANK RECONSTRUCTION}

Title $\mathrm{X}$ of the Dodd-Frank Act seeks to remedy these flaws through a major reconstruction of the consumer financial protection structure in the United States..$^{8}$ Congress employed several strategies, including institutional design. The Act creates the Consumer Financial Protection Bureau as a new, independent federal agency located within the Federal Reserve,59 while ensuring the agency's autonomy. ${ }^{60}$ To promote the agency's independence, Congress created a set funding stream as a percentage of the Fed's annual earnings. ${ }^{61}$ Moreover, the President appoints a Director, subject to the

"banking agencies" (also referred to as the "prudential regulators") include the Office of the Comptroller of the Currency, the Board of Governors of the Federal Reserve System, the Federal Deposit Insurance Corporation, the National Credit Union Administration, and the former Office of Thrift Supervision, which the Dodd-Frank Act abolished. See 12 U.S.C. $\S 5481(24)$.

54. See Bar-Gill \& Warren, supra note 2, at go.

55. See generally DONALD RESSEguIE, BANKING LAW $§ 1.04$ (2012).

56. See ENGEL \& MCCOY, supra note 3, at 159-61; Bar-Gill \& Warren, supra note 2, at 9394; Wilmarth, supra note 3 , at 915 .

57. For several examples of state banks that converted to national banks after OCC issued its preemptions rules, see ENGEL \& MCCOY, supra note 3, at 159-61.

58. See generally Michael B. Mierzewski et al., The Dodd-Frank Act Establishes the Bureau of Consumer Financial Protection as the Primary Regulator of Consumer Financial Products and Services, 127 BANKING L.J. 722 (2010); Wilmarth, supra note 3, at 920-48.

59. Dodd-Frank Wall Street Reform and Consumer Protection Act, Pub. L. No. 111-203, $\S 1011,124$ Stat. $1376(2010)$.

6o. Id. $\$ 1012(\mathrm{c})$.

61. Id. $\$ 1017(\mathrm{a})$. 
advice and consent of the Senate, for a five-year term. ${ }^{62}$ The Director is subject to removal only for cause. ${ }^{63}$

Having witnessed the deleterious effects of a conflicted mission within the banking agencies, Congress charged the CFPB with the sole mission of protecting consumers. "The Bureau shall seek to implement and, where applicable, enforce Federal consumer financial law consistently for the purpose of ensuring that all consumers have access to markets for consumer financial products and services and that markets for consumer financial products and services are fair, transparent, and competitive." $6_{4}$

In addition, Congress departed from the institutional fragmentation that marked the consumer financial protection system leading up to the economic crisis, giving CFPB broad and comprehensive authority to "regulate the offering and provision of consumer financial products or services under the Federal consumer financial laws." $6_{5}$ This transfer of consumer protection powers to the CFPB is sweeping. With a few exceptions, ${ }^{66}$ the Act defines "Federal consumer financial law[s]" to include nearly all laws that safeguard consumer participation in the financial marketplace, and any regulations under those laws. ${ }^{67}$ These laws include, amongst others, TILA, HOEPA, the Fair Credit Reporting Act ("FCRA"), and the Real Estate Settlement Procedures Act ("RESPA"). ${ }^{68}$ Further, Title X also creates new protections, including a broad prohibition on "unfair, deceptive, or abusive act[s] or practice[s]" ("UDAAPs"). ${ }^{69}$ This prohibition extends to any "covered person," which the Act defines as "any person that engages in offering or providing a consumer financial product or service,"70 as well as any "service provider," which means "any person that provides a

\footnotetext{
62. Id. \$1011.

63. Id. $\$ 1011(\mathrm{c})(3)$.

64. 12 U.S.C. $\$ 55^{11(a)}(2012)$.

65. Id. $\$ 5491$ (a).
}

66. Persons and services exempted from the agency's authority include merchants or sellers of nonfinancial goods or services that extend credit directly to consumers for the sole purpose of allowing consumers to purchase those nonfinancial goods or services, real estate brokers, sellers of manufactured or modular homes, accountants and tax preparers, attorneys, employee benefit and compensation plan providers, insurance and reinsurance providers, and persons regulated by a state securities commission. $I d$. $\$ \$ 55^{1} 7$ (a) (1), $54^{81}$ (15)(C)(i).

67. Id. $\$ 5481(14)$. For a list of the rules over which the CFPB has authority, see Identification of Enforceable Rules and Orders, 76 Fed. Reg. 43.569 (July 21, 2011 ).

68. 12 U.S.C. $\$ 5481(12)$.

69. Id. $\$ 5536(\mathrm{a})(\mathrm{1})(\mathrm{B})$.

70. Id. $\S 5481(6)$. Financial products and services include the extension of credit and servicing of loans; real estate settlement services; taking deposits; transmitting or exchanging funds; selling, providing, or issuing gift cards or other store value or payment instruments; providing check cashing, collection, and guaranty services; payment or other financial data processing products or services; financial advisory services; and the collection and provision of consumer report and credit history information. Id. $\$ 5481$ (15). 
material service to a covered person" in the offering of such product or service. $7^{1}$

The CFPB's authority with respect to the federal consumer financial laws includes rulemaking, supervisory, and enforcement powers. Congress gave the CFPB exclusive rulemaking power, $7^{2}$ subject to override by a twothirds vote of the Financial Stability Oversight Council ("FSOC").73 In addition, for the first time Congress gave a federal agency power to supervise nondepositories.74 These institutions include many mortgage lenders and servicers, private student lenders, payday lenders, and any "larger participant" in the market for consumer financial products and services, which the CFPB has defined to include the major credit reporting agencies 75 and debt collectors. $7^{6}$ Moreover, the agency has supervisory power over depositories with assets greater than $\$ 10$ billion. 77

Finally, the CFPB also has extensive enforcement powers. With respect to the above-mentioned nondepositories, the CFPB has exclusive enforcement authority among federal regulators. $7^{8}$ As to depositories, the CFPB has primary enforcement authority with respect to depositories with assets greater than $\$ 10$ billion.79 For depositories with less than $\$ 10$ billion in assets, the prudential regulator retains exclusive enforcement authority among federal regulators. ${ }^{80}$ In bringing enforcement actions, the agency has a wide range of tools to issue civil investigative demands, ${ }^{81}$ bring

71. Id. $\S 5481(26)$.

72. Id. $\$ 5512$ (b)(1), (4). The one exception is concurrent powers between the CFPB and the FTC, and a statutory requirement that the two agencies coordinate rulemaking. Id.

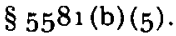

73. Id. $\$ 55_{13}(\mathrm{a})$, (c). The Financial Stability Oversight Council ("FSOC") includes the Treasury Secretary, the Fed Chairman, the Comptroller of the Currency, the CFPB Director, the FTC Chairman, the FDIC Chairperson, the Commodity Futures Trading Commission Chairperson, the Federal Housing Finance Agency Director, the National Credit Union Administration Chairman, and a presidential appointee with insurance expertise. Id. $\$ 5491$ (b).

74. Id. $\$ 55^{1} 4(\mathrm{a})$.

75. Defining Larger Participants of the Consumer Reporting Market, 77 Fed. Reg. 42,874 (July 20, 2012).

76. Defining Larger Participants of the Consumer Debt Collection Market, 77 Fed. Reg. 65,775 (Oct. 31,2012 ).

77. Id. $\$ 55^{1} 5$. Depositories with assets of less than $\$ 10$ billion are supervised by their prudential regulators for compliance with Federal consumer financial law, although the CFPB has a limited role to include examiners on a sampling basis. Id. $\$ 55^{16}$. For a list of depositories that the CFPB currently supervises, see CFPB, CFPB DEPOSITORY [INSTITUTIONS] (CFPB DI's) BASED ON 6/30/12 TOTAL ASSETS (2012), available at http://files.consumerfinance.gov/ f/201206_CFPB_depository-institutions-list.pdf.

78. 12 U.S.C. $\$ 55^{14}(\mathrm{c})$.

79. Id. $\S 55^{1} 5^{(\mathrm{c})}$.

8o. Id. $\$ 55^{16(d)}$. See supra note 53 and accompanying text for an explanation of a "prudential regulator."

81. 12 U.S.C. $\$ 55^{62}(\mathrm{~d})$. 
administrative proceedings ${ }^{82}$ or civil actions, ${ }^{83}$ and seek a range of remedies including rescission or reformation of contracts, refund of money or return of real property, restitution, disgorgement, damages, public notification, limitation on future activities, and civil penalties. ${ }^{84}$

These reforms aim to create an agency that exercises its power to protect consumers in the financial marketplace. But Congress went further in Title $\mathrm{X}$ by adopting several new substantive laws governing consumer financial products and services. These new rules, including the broad UDAAP ban and provisions covering mortgage originators under Title XIV, represent a shift from disclosure-based rules to regulation that reaches the substance of deals and assesses whether consumers understand the terms disclosed. ${ }^{85}$

Finally, Congress sought to enlist the states by employing federalismbased strategies, including new limits on agency preemption. ${ }^{86}$ Rejecting the premise that federal law occupies the field, Congress opted for a form of conflict preemption. State laws are preempted only to the extent they are "inconsistent with the provisions [Title X of the Dodd-Frank Act], and then only to the extent of the inconsistency." 87 A state provision is not inconsistent if the protection it "affords to consumers is greater than the protection provided under this title." 88 In other words, federal law is a floor, not a ceiling.

\section{INNOVATION}

The creation of one federal agency vested with the authority and incentives to protect consumers in the financial marketplace, the adoption of new substantive rules, and the securing of a space for states to enforce state law are all innovations Congress employed to reconstruct the system of consumer financial protection in the United States. But Congress also vested states-and in particular state attorneys general-with power to enforce federal law. Although I will return to this point in Part IV, this innovation

82. $\quad I d . \S 5563$ (d).

83. Id. $\$ 55^{6} 4(\mathrm{~d})$.

84. Id. $\$ 55^{6} 6_{5}(\mathrm{~d})$.

85. As Dee Pridgen argues, these rules mark "a sea change, or paradigm shift, in the basic underlying theories of consumer protection [, as] reflected in ... the shift from the use of pure disclosures under the rational choice theory of economics, to a system based on the more realistic view of consumer decision making as revealed by behavioral economics." Dee Pridgen, Sea Changes in Consumer Financial Protection: Stronger Bureau and Stronger Laws, 13 WYo. L. REV. (forthcoming 2013), available at http://ssrn.com/abstract=2186o35; see also Jean Braucher, Form and Substance in Consumer Financial Protection, 7 BROOK. J. CORP. FiN. COM. L. (forthcoming 2013), available at http://ssm.com/abstract $=2126859$.

86. See Wilmarth, supra note 3 , at $920-48$.

87. 12 U.S.C. $\$ 5551$ (d).

88. Id. Congress defined a specific preemption standard for national banks and subsidiaries. Id. $\$ 55^{8} 7$. 
promises several benefits: it serves as a force-multiplier; it places increased authority in the hands of state actors who have local knowledge that federal actors may lack; and it fosters accountability, democratic participation, and innovation. ${ }^{89}$

In this Part, I describe the concurrent-enforcement powers enjoyed by SAGs under the Dodd-Frank Act, while considering critical interpretive issues that will determine their breadth. I begin by looking at the scope of the substantive powers. I then turn to procedural and remedial powers, as the ability of states to exercise substantive powers will often depend on them. I explore these remedial and procedural powers, along with the interpretive issues they raise, against the backdrop of state constitutional, statutory, and common law powers that shape the offices of SAGs.

\section{A. SUBSTANTIVE POWERS}

Congress has experimented in the past with dual-enforcement regimes. $9^{\circ}$ Title $\mathrm{X}$, however, is one of the largest dual-enforcement attempts to date, and is additionally the first comprehensive scheme in the area of consumer protection..$^{1}$ In four earlier instances Congress gave SAGs limited and scattered powers to enforce federal laws affecting consumer finance. In $198_{3}$ Congress amended the Real Estate Settlement Procedures Act to give SAGs authority to enforce the statute's anti-kickback provision, prohibiting any exchange of value for referring business in a real estate transaction. $9^{2}$ Several years later Congress amended TILA to require enhanced disclosure and trigger special substantive limitations on certain high-cost mortgages. 93 This amendment, called the Home Ownership Equity Protection Act of 1994, gave SAGs power to enforce these provisions.94 Then in 1996

89. Most obviously, despite attempts to insulate CFPB from capture, the powers of the agency rest in the hands of the Director who is appointed by the President and will likely reflect the ideological leanings of a particular administration. See, e.g., Jenna Greene, Youngest Agency Has a Lot on the Line, NAT'L L.J. (Oct. 29, 2012), http://www.law.com/jsp/nlj/Pub ArticleNLJ.jsp?id=1 202576494717 (“A director who is more sympathetic to industry concerns could essentially 'babysit' the agency." (quoting Patricia Trendacosta, managing partner of Frandzel Robins Bloom \& Csato)).

9o. See Lemos, supra note 4 , at notes $4^{0-61}$ and accompanying text; Widman \& Cox, supra note 4 , at 8-27 and accompanying text.

91. Ashley L. Taylor, Jr. et al., The Consumer Financial Protection Bureau and the State Attorneys General: A Force Multiplier in Consumer Protection Matters, BLOOMBERG L. REP. (May 25, 2011), http://www.troutmansanders.com/files/Uploads/Documents/Bloomberg\% 2oLaw\%2oByline. pdf ("Coordinated regulatory enforcement among federal and [s] tate governments is not a new phenomenon; however, coordination has not been previously contemplated on such grand a scale as anticipated under Dodd-Frank.").

92. Supplemental Appropriations Act of 1983 , Pub. L. No. 98-181, $\$ 461$ (c), 97 Stat. $1153,1232-33$ (codified as amended at 12 U.S.C. $\$ 2607$ (d) (4) (2012)).

93. Riegle Community Development and Regulatory Improvement Act of 1994, Pub. L. No. $103-325, \S \S 15^{1-1} 5^{8}, 108$ Stat. $2190,2190-98$ (codified as amended at 15 U.S.C.)

94. II. § 153 (b). 
Congress gave states power to enforce federal law governing the creation, maintenance, and use of consumer credit reports under an amendment to the FCRA.95 And finally in 2009, as a prelude to the Dodd-Frank Act, Congress gave SAGs authority to enforce any rules the Federal Trade Commission prescribed to prevent UDAP in mortgage lending. ${ }^{6}$ SAGs have been especially active enforcing rules that regulate so-called "foreclosure rescue" services. 97

Although the 2009 Amendment incorporated by the Dodd-Frank Act is an important grant of power, the other three aforementioned, state attorney-general enforceable amendments are relatively narrow and have remained largely unexercised by the states. $9^{8}$ Prior to passage of the DoddFrank Act, state attorneys general played a peripheral, ad hoc role in the

95. Consumer Credit Reporting Reform Act of 1996, Pub. L. No. 104-208, § 2417,110 Stat. 3435,3460 (codified as amended at 15 U.S.C.A. $\$ 1681 \mathrm{~s}(\mathrm{c})(1)(2006)$ ).

96. Omnibus Appropriations Act of 2009, Pub. L. No. 111-8, $\$ 626$ (b) (1), 123 Stat. $5^{24}$, $678-79$ (codified as amended at 12 U.S.C. $\$ 5538(\mathrm{~b})(1)(2012)$ ). The story is more complicated than the in-text sentence summary suggests. The original 2009 amendment, passed on March 11, 2009, required the FTC to issue mortgage rules to prevent UDAP. Id. $\$ 626$ (a). The amendment did not make clear whether these rules would apply against federally chartered depositories. As explained earlier, see Williams \& Bylsma, supra note 17, at 1 243-49 and accompanying text, the Federal Trade Commission Act expressly prohibited the application of FTC rules to these institutions. In addition, for a short time Congress also gave SAGs power to enforce the whole of TILA and any mortgage rules prescribed under it by the FTC. Omnibus Appropriations Act $\$ 626(b)(1)$. Two months later, however, Congress limited this concurrent-enforcement power to only FTC rules meant to prevent UDAP in mortgage loans, including loan modification and foreclosure rescue services. Credit Card Accountability Responsibility and Disclosure Act of 2009 , Pub. L. No. $111-24, \S 511$ (a) (2) (A), 123 Stat. 1734 , ${ }_{17} 6_{3}-64$ (codified as amended at 12 U.S.C. $\$ 553^{8(a)(3)}(2012)$ ). With Title XIV of the Dodd-Frank Act, Congress placed the power to make mortgage rules in the hands of the CFPB and left SAG's power to enforce these rules largely unchanged. Dodd-Frank Wall Street Reform and Consumer Protection Act of 2010, Pub. L. No. 111-203, §1097, 124 Stat. 1376, $2102-03$ (codified as amended at 12 U.S.C. $\$ 5538$ (a) (1) (2012)).

97. The CFPB has issued the Mortgage Assistance Relief Services ("MARS") Rule (Regulation O) under this provision, which regulates foreclosure relief and other services. See Mortgage Assistance Relief Services (Regulation O), 12 C.F.R. \$\$1015.1-11 (2011). Among other provisions, the MARS Rule prohibits these services from collecting an upfront fee. Id. $\S 1015.5$ (a). State attorneys general have actively enforced this prohibition. See, e.g., Bryan Cohen, Colo. AG Puts End to Alleged Scheme, LeGal NEwSLine (Mar. 22, 2012, $12: 14$ PM), http://legalnewsline.com/news $/ 2355^{8} 5$-colo-ag-puts-end-to-alleged-scheme.

98. A recent study regarding SAG use of concurrentenforcement powers found no instances where states had acted under RESPA, four instances where states used their FCRA powers, and five instances where they used their HOEPA powers. Widman \& Cox, supra note 4 , at 71-72. The limited use of the HOEPA power is in part explained by the narrowness of the statute, which applied only to loans meeting high threshold criteria. See Robert B. Avery et al., The 2006 HMDA Data, 93 FED. RES. BULL. A73, 88 (2007) ("In the aggregate, HOEPA related lending accounts for a very small proportion of the loan market: HOEPA loans accounted for less than 0.1 percent of all the originations of home-secured refinancings and homeimprovement loans reported for 2006 ...."). To strengthen protection, Congress amended HOEPA in the Dodd-Frank Act. See Dodd-Frank Wall Street Reform and Consumer Protection Act $\$ \S 1431-33$. 
enforcement of federal consumer financial protection law. Now, with the Act, they have the potential to be lead actors, including the power to enforce federal law even when the CFPB lacks authority.

Title $X$ carves out broad dual-enforcement authority: SAGs are empowered "to enforce provisions of this title or regulations issued under this title."99 The Act places two limits on this power, one substantive and the other procedural. First, the Act prohibits SAGs from enforcing any provision of Title X against a federally chartered depository, although it permits states "to enforce a regulation prescribed by the Bureau under a provision of this title ...." requires states to give notice to the CFPB before bringing any enforcement action under Title $\mathrm{X}$, and gives the federal agency powers of intervention, removal, and appeal. ${ }^{\circ 1}$ In addition to powers under Title X, SAGs may also enforce new substantive rules governing mortgages under Title XIV. ${ }^{102}$ I will examine these powers in three categories: the power to enforce the general UDAAP ban, other federal consumer financial protection laws, and new substantive limits on mortgage terms.

\section{UDAAP Ban}

The single most important power the Dodd-Frank Act confers on SAGs is the power to enforce the Act's new prohibition on any "unfair, deceptive, or abusive act or practice,"1os and any rules the CFPB promulgates under this prohibition. ${ }^{104}$ Like its federal cousin, UDAP, this new prohibition and the agency's power to make rules under it provides critical flexibility to respond to emerging threats in the market that by design or effect harm consumers. ${ }^{105}$ At the same time, as with any standard, poor implementation can generate uncertainty, chill innovation, and harm consumers. To understand the significance of this authority, we must understand the evolution of the UDAAP ban out of federal consumer protection law, the scope of the new UDAAP provision, and the significance of this allowance in light of the authority SAGs currently have under state law to prevent unfair and deceptive acts or practices.

Although it breaks new ground, the UDAAP ban bears a close connection to the longstanding prohibition on "unfair or deceptive acts or

99. 12 U.S.C. $\$ 555^{2}(2012)$. This power is placed in the hands of the state attorney general, but $\S 5552$ (a) (1) also gives a similar power to "[a] state regulator." Id.

1oo. Id. $\S 555^{2}(\mathrm{a})(2)$.

101. Id. $\S 555^{2}$ (b) (1)(A).

102. Id. $\$ 555^{2}$.

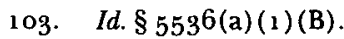

104. Id. $\$ \S 5536(\mathrm{a})-(\mathrm{b})$.

105. See Bar-Gill \& Warren, supra note 2, at $84-85$ (discussing the benefits of an administrative approach under a broad statutory standard). 
practices" under section 5 of the Federal Trade Commission Act. ${ }^{106}$ Recall that the UDAP ban was added to the FTCA in 1938, with Congress giving authority over federal depositories to various federal banking regulators. ${ }^{107}$ Title $\mathrm{X}$ transferred exclusive rulemaking power to the CFPB, ${ }^{108}$ while adding a ban on "abusive" acts and practices. ${ }^{109}$ The CFPB has exclusive enforcement authority as to banks with more than $\$ 10$ billion in assets. ${ }^{10}$ In addition, Congress created a sphere of largely overlapping enforcement authority between the CFPB and the FTC."

Perhaps the most asked question under the UDAAP ban is how the CFPB will interpret its scope, especially its new ban on "abusive" acts or practices. Both Title $\mathrm{X}$ and subsequent agency statements give a reasonably clear indication of how the agency will interpret "unfair" and "deceptive." The statutory definition of "unfairness" 12 is the same definition the FTC has long recognized under UDAP." $"$ Title $X$ is silent as to the meaning of "deceptive," perhaps because the FTCA also does not define the term. The

\footnotetext{
106. 15 U.S.C. $\$ 45$ (a) (1) (2006).

107. See supra notes $13^{-16}$ and accompanying text.

108. 12 U.S.C. $\$ 553^{1}$ (b); 15 U.S.C. $\$ 109^{2}$ (2006 \& Supp. IV 2011 ).

109. 12 U.S.C. $\$ 5536$ (a) (1) (B).

$110 . \quad I d . \S 55^{1} 5(\mathrm{a})-(\mathrm{b})$.
}

111. Title X makes clear that it does not alter or limit the existing powers of the FTC, other than the transfer of rulemaking powers under federal consumer financial law. Id. $\S 5581$ (b) (5)(C) (i). Although the FTC does not have authority over banks, savings and loan associations, or federal credit unions, the agency and the CFPB still have overlapping authority as to a wide range of individuals and institutions involved in consumer finance, including nonbank mortgage lenders, private student lenders, credit card companies, payday lenders, and credit bureaus. See ${ }_{15}$ U.S.C. $\$ 45$ (a) (2) (FTC power); 12 U.S.C. $\$ 5531$ (a)-(b) (CFPB power). In each case, the FTC has power under FTCA's UDAP ban, and the CFPB has power under Title X's UDAAP ban. On account of this overlap, Title $\mathrm{X}$ requires the two agencies to negotiate an agreement with respect to rulemaking so as to avoid duplication or conflict between rules prescribed by each agency. 12 U.S.C. $\$ 55^{81}$ (b) (5)(D). The heads of both agencies signed this agreement on January 20, 2012. CONSUMER Fin. Prot. Bureau \& FED. TRADE COMm'N, MEMorandum OF UNDERSTANDing BETWEen the CONSUMER Financial PROTECTION BuREAU AND THE FEDERAL TRADE COMMISSION (2012), available at http://files.consumerfinance.gov/f/ 2012/01/FTC.MOUwSig.1.20.pdf. Moreover, Title $X$ gives the agencies mutual power to enforce regulations under both UDAP and UDAAP, as long as the agency otherwise has jurisdiction over the person. 12 U.S.C. $\$ 55^{81}$ (b) (5) (B) (ii), (C) (ii).

112. 12 U.S.C. $\$ 5531$ (c)(1)(A)-(B) (defining "unfair" to require that "the act or practice causes or is likely to cause substantial injury to consumers which is not reasonably avoidable by consumers; and ... such substantial injury is not outweighed by countervailing benefits to consumers or to competition").

113. See FED. TRADE COMM'N, FTC POLICY StATEMENT ON UNFAIRNESS (1980), available at http://www.ftc.gov/bcp/policystmt/ad-unfair.htm. Congress later amended the FTCA to incorporate this standard in the statute. Federal Trade Commission Act Amendments of 1994, Pub. L. No. $103-312, \S 9,108$ Stat. 1691,1695 (codified as amended at 15 U.S.C. $\S 45$ (n) (2006)). 
CFPB, however, has made clear'14 that it intends to follow the FTC's longstanding definition. ${ }^{115}$

Less clear is how CFPB will interpret "abusive," which has caused some consternation in the regulated community." Although the term has appeared in other laws, neither Congress nor the agencies have given it much attention. ${ }^{17}$ Nonetheless, the meaning of the term is not an interpretive grab-bag. Congress said an actor or practice is abusive if it:

(1) materially interferes with the ability of a consumer to understand a term or condition of a consumer financial product or service; or

(2) takes unreasonable advantage of-

(A) a lack of understanding on the part of the consumer of the material risks, costs, or conditions of the product or service;

(B) the inability of the consumer to protect the interests of the consumer in selecting or using a consumer financial product or service; or

(C) the reasonable reliance by the consumer on a covered person to act in the interests of the consumer. ${ }^{118}$

For now, the CFPB has only repeated the statutory definition and made clear that it interprets "abusive" as a distinct term, even though its meaning may overlap with the definitions of "unfair" and "deceptive."19 The definition, however, gives some clues as to how UDAAP may add further protections. Most important, the term has a subjective dimension insofar as

1 14. See Consumer Fin. Prot. Bureau, CFPB Supervision and Examination manual VERSION 2.o, UDAAP 5 (2012), available at http://files.consumerfinance.gov/f/201210_ cfpb_supervision-and-examination-manual-v2.pdf. The CFPB further suggests it will hew close to the FTC's definitions of unfair and deceptive insofar as it draws on numerous examples taken from FTC enforcement actions. Id. at UDAAP 2-8.

115. See Fed. TRADE COMM'N, FTC POLICY STATEMENT ON DECEPTION (1983), available at http://www.ftc.gov/bcp/policystmt/ad-decept.htm ("[T]he Commission will find deception if there is a representation, omission or practice that is likely to mislead the consumer acting reasonably in the circumstances, to the consumer's detriment.").

1 16. See, e.g., Cheyenne Hopkins, 'Chilling Effect' of 'Abusive' in Dodd-Frank, 15 AM. BANKER 1 (2010).

117 . See, e.g., 15 U.S.C. $\$ 16 g_{2}$ (e) ("It is the purpose of this subchapter to eliminate abusive debt collection practices by debt collectors, to insure that those debt collectors who refrain from using abusive debt collection practices are not competitively disadvantaged, and to promote consistent State action to protect consumers against debt collection abuses."); id.

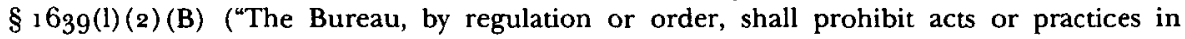
connection with ... refinancing of mortgage loans that the Bureau finds to be associated with abusive lending practices, or that are otherwise not in the interest of the borrower.").

118 . 12 U.S.C. $\$ 553^{1}$ (d) (2012).

119. See Consumer Fin. Prot. Bureau, CFPB Supervision and Examination manual. VERSION 2.o, supra note 114 , at UDAAP 9. 
it looks to the (likely, "reasonable") consumer's perception and understanding. In the end, the meaning of the term will depend on how the CFPB interprets and enforces the provision, and likely how state attorneys general do the same.

One place this new term may allow SAGs to better protect consumers is to curtail "steering," whereby lenders or other credit providers direct customers in the first instance to products that may not provide them with the best terms for which they qualify. Steering is effective in part because many consumers who sit down with a lender trust that the person on the other side of the table will tell them about the best available deal. The amendments to TILA in Title XIV ban financial incentives that promote this practice among home mortgage lenders.120 But the practice happens in other areas, as well. In particular, SAGs might use this new power to prevent steering practices among private student lenders. This practice occurs now when private lenders steer students to take larger loans than they really need. A SAG might also argue that steering occurs when a private lender fails to tell a student about the availability of more advantageous federal students loans for which the student possibly qualifies. ${ }^{121}$

To understand the significance of Congress's decision to extend enforcement power of the new UDAAP ban to states, we need to understand the scope of SAG powers to stop unfair and deceptive practices under state law. Although state UDAP laws are a key protection for consumers in the financial marketplace, they also have limitations. In many states the power of SAGs to enforce their state's consumer protection act is limited because of weak substantive prohibitions. ${ }^{122}$ A strong statute includes a ban on unfair and deceptive practices, like the federal UDAP ban. ${ }^{123}$ Some states, however, prohibit only specific acts, requiring the legislature to enumerate new harms on a case-by-case basis. Colorado ${ }^{124}$ and Indiana, ${ }^{125}$ for example, do not prohibit "deception," but only certain specifically enumerated deceptive acts.

Another substantive weakness in many state UDAP laws concerns the scope of application: which individuals or entities SAGs can reach. Some states include exemptions for certain industries. The Virginia Consumer Protection Act, for example, exempts nearly all of the credit industry. ${ }^{126}$

120. 12 U.S.C. $\S 1639 b(c)$.

121. See Tiffany S. Lee, No More Abuse: The Dodd-Frank and Consumer Financial Protection Act's 'Abusive' Standard, 14 J. CONSUMER \& COM. L. 118, 126-27 (2011).

1 22. See Carolyn L. Carter, nat'l Consumer law Ctr., Consumer Protection in the STATES: A 5O-STATE REPORT ON UNFAIR AND DECEPTIVE ACTS AND PRACTICES STATUTES (2009), available at http://www.nclc.org/images/pdf/udap/report_50_states.pdf.

123. 15 U.S.C. $\$ 45$ (a) (1) (2006).

124. Colo. Rev. STAT \& 6-1-105(1) (2009).

125. IND. CODE § 24-5-0.5-3 (1993 \& Supp. 1997).

126. VA. CODE ANN. § 59.1-199(D) (2007). 
Michigan provides the most glaring example. Although on paper the state has otherwise robust protections for consumers, ${ }^{127}$ the Michigan Supreme Court has vitiated the act by interpreting it to exempt any industry subject to state regulation or licensing-an exemption that swallows the rule. ${ }^{128}$ Moreover, some states such as Nevada'129 and North Dakota ${ }^{130}$ follow the common law and require proof of knowledge or intent, which can also stand as an obstacle to relief. And finally, some state UDAP laws provide weak remedies. Although nearly all states allow for civil penalties, in some states like Rhode Island, ${ }^{191}$ Pennsylvania, ${ }^{132}$ and Missouri, ${ }^{133}$ a low cap on initial violations compromises effective deterrence. ${ }^{134}$

For the many states with significant gaps in state law, Congress's decision to give SAGs the power to enforce the new UDAAP ban is highly significant. In some states, SAGs can now reach industries previously exempt under state law either by express provision or judicial interpretation. ${ }^{1} 35$ SAGs in many states now also have flexibility where the state-UDAP only applies to

127. MICH. COMP. LAWS ANN. \$ 445.901-22 (West 2002 \& Supp. 2005).

128. See Liss v. Lewiston-Richards, Inc., $73^{2}$ N.W.2d 514 (Mich. 2007); Smith v. Globe Life Ins. Co., 597 N.W.2d 28 (Mich. 1999).

129. NEV. REV. STAT. $\$ 589 \cdot 0915$ (2000).

130. N.D. CENT. CODE $\$ 5^{1-1} 5^{-02}(2007)$.

131. R.I. GEN. LAWS $\$ 6-13.1-8$ (2011) (limiting civil penalties to subsequent violations of an injunction).

132. PA. CONS. STAT. $\$ 201-8$ (b) (Supp. 2005) (limiting civil penalties to $\$ 1$,ooo per violation for initial violations).

133. MO. REV. STAT. $\$ 407.100(6)$ (2000) (limiting civil penalties to $\$ 1$,ooo per violation for initial violations).

134. As suggested earlier, supra notes $48-52$ and accompanying text, the power of SAGs under state UDAP laws has also been limited because of the threat that federal regulators will preempt application of these laws against federally chartered depositories. Most immediately, these preemption claims applied to laws that directly regulated these institutions, such as state predatory lending laws. Both the OCC and the OTS issued rules stating that their preemptive directives did not extend to generally applicable state laws, such as those governing contracts, commercial transactions, and real property, insofar as such laws only had an incidental effect on the federal depository. See Lending and Investment, 61 Fed. Reg. 50,951, 50,972 (Sept. 3o, 1996) (codified at 12 C.F.R. $\$ 560.2(\mathrm{c})$ ) (OTS); Bank Activities and Operations, 69 Fed. Reg. 1904,1917 (Jan. 13, 2004) (codified at 12 C.F.R. $\$ \S 7.4007$ (c), 7.4008(e)) (OCC). However, statements made by the OCC and the OTS have left some confusion. See CAROLYN L. CARTER \& Jonathan Sheldon, Unfair And Deceptive ACts ANd Practices $\$ \S 2.5 \cdot 3 \cdot 2-3 \cdot 3$ (8th ed. 2012 ). Further, in some cases these claims to preemption also applied to state UDAP laws when courts determined that the plaintiff was using the state's general prohibition on unfair and deceptive acts or practices to accomplish what a specific law was otherwise preempted from achieving. See id. (listing cites). Although Title X of the Dodd-Frank Act does not expressly address state UDAP laws, as a whole it suggests that SAGs can still enforce these laws against federal depositories, that the scope of preemption has narrowed, and that case-by-case preemption will apply. See Raymond H. Brescia, Leverage: State Enforcement Actions in the Wake of the Robo-Sign Scandal, 64 ME. L. REV. 17, 32-43 (2011) (arguing, similarly, that SAGs can still enforce these laws against federal depositories, that the scope of preemption has narrowed, and that case-by-case preemption applies); supra notes 88-90 and accompanying text.

135. See supra notes $126-28$ and accompanying text. 
enumerated acts or practices, or in states that lack either of the unfair or deceptive prohibitions. ${ }^{13^{6}}$ Moreover, for all states this power is extended to cover abusive acts or practices. ${ }^{237}$ The range of civil penalties may also be much greater under UDAAP, which range from a maximum of $\$ 5000$ per violation per day, up to $\$ 25$,ooo if the violation is reckless, and $\$ 1$ million if the same is knowing. ${ }^{13^{8}}$ And lastly, the availability of the federal UDAAP to SAGs may bolster the case against preemption of state UDAP laws. At a minimum it allows the state to enforce any of the CFPB's regulations under the federal UDAAP against federal depositories. Among the substantive provisions that Congress empowered SAGs to enforce, the UDAAP ban is the most important and for many states has the potential to fill critical gaps. ${ }^{139}$

\section{Other Federal Consumer Financial Protection Laws}

Despite receiving much less attention than the meaning of the new "abusive" prohibition, another critical and contested interpretive issue determining the scope of SAG enforcement powers is whether these powers extend beyond UDAAP and accompanying regulations. Do states have the power to enforce the whole of "federal consumer financial law," including the eighteen federal statutes that fall under this term (referred to as the "enumerated consumer laws") as defined by Title $\mathrm{X}$, and any regulations under those statutes? ${ }^{2} 4^{\circ}$ Both a narrow and a broad reading of Title $\mathrm{X}$ acknowledge, as the statute requires, that-whatever their enforcement powers-SAGs are limited to enforcing the CFPB's regulations against

136. See supra notes $123-25$ and accompanying text.

137. See supra note $116-19$ and accompanying text.

138. 12 U.S.C. $\$ 55^{65}$ (c) (2012).

139. In addition to UDAAP regulations, SAGs can also enforce other rules under Title $\mathrm{X}$ provisions that the CFPB might one day promulgate. See, e.g., id. $\$ 5532$ (a) (granting the CFPB the power to prescribe rules to "ensure that the features of any consumer financial product or service . . . are fully, accurately, and effectively disclosed to consumers"); $i d$. $\$ 5533$ (a) (granting the CFPB the power to ensure consumer access to information regarding a consumer financial product or service); id. $\$ 55^{18(b)}$ (granting the CFPB the power to limit or even ban mandatory pre-dispute arbitration agreements). This latter power could be especially important, given recent attention to such agreements and their consequences for consumer protection. See, e.g., Maria Aspan, Issuers Moving Away from Arbitration, 174 AM. BANkER 16 (July 23, 2009); Zachary Gima et al., Forced Arbitration: Unfair and Everywhere, PUB. CrTIZEN (Sept. 14, 2009), http://www.citizen.org/documents/UnfairAndEverywhere.pdf; Robert J. Hobbs \& Rick Jurgens, Forced Arbitration: Consumers Need Permanent Relief, NAT'L CONSUMER LAW CTR. (Apr., 2010), http://www.nclc.org/images/pdf/arbitration/report-forced-arbitration.pdf; Firm Agrees to End Role in Arbitrating Card Debt, N.Y. TIMES (July 19, 20og), http://www.nytimes.com/ 2009/o7/20/business/2ocredit.html?_r=o. Because the U.S. Supreme Court has concluded that state laws banning mandatory pre-dispute arbitration agreements are preempted by federal law, Allied-Bruce Terminix Companies, Inc. v. Dobson, $5^{13}$ U.S. $26_{5}, 281$ (1995), if the CFPB exercises its discretionary power to limit or prohibit these agreements, these rules would give SAGs considerable enforcement powers that they do not currently possess.

140. 12 U.S.C. $\$ 5481(12),(14)(2012)$. 
federal depositories. ${ }^{14^{1}}$ The narrow reading of the statute, however, says that SAGs can only enforce UDAAP and any other substantive provisions created by Title $\mathrm{X}$. The broad reading says that SAGs can enforce UDAAP, but can also enforce the whole of federal consumer financial protection law: all the pre-existing statutes, and the regulations under them.

Even if the narrow reading is correct, the Dodd-Frank Act still gives states extraordinary power to enforce federal law. Nonetheless, the implications of which reading prevails are highly significant, given the scope of laws at stake. ${ }^{14^{2}}$ Although few stakeholders have weighed in on this issue, the ones that have expressed an opinion mirror the range of interpretive options. The National Consumer Law Center ${ }^{143}$ and the National Association of Attorneys General ${ }^{144}$ have both issued statements that favor the broad reading of the statute, while many of the large law firms (who represent the regulated community) ${ }^{145}$ have favored the narrow reading. The CFPB has been silent on the matter, except to say that the section $104^{2}$ notice requirement when a state enforces a federal law under that section "does not apply to actions brought under the enumerated consumer laws . ..." ${ }^{6} 4^{6}$ If the agency does interpret the statute on this point, whether it gets the final word will depend on whether the courts determine that the statute is ambiguous. Although Congress could have written with more clarity, for the reasons that follow I believe the broad reading aligns more closely with the statutory text.

The interpretive problem arises under Title $X$, section 1042, which creates dual-enforcement powers. Congress allowed state attorneys general to "bring a civil action ... to enforce provisions of this title or regulations

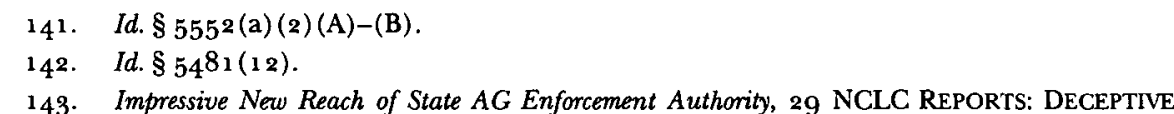
PRACTICES \& WARRANTIES ED. Jan.-Feb. 2011 , at 18 ("The Dodd-Frank Act appears to provide attorneys general . . . the authority to enforce most federal consumer credit legislation-even when the other legislation does not grant the attorneys general this authority. This result is consistent with the intent of the Dodd-Frank Act to 'put more cops on the beat' by empowering state attorneys general to police the market.").

144. NAT'L ASS'N OF ATT'YS GEN., WALL STREET REFORM AND CONSUMER PROTECTION AGT: SUMMARY FOR ATTORNEYS GENERAL 6 (2010), available at http://www.naag.org/assets/files/ $\mathrm{pdf} / \mathrm{pubs} /$ wall-street-reform-UB.pdf (noting that 12 U.S.C. $\S 555^{2}$ (a) (1) gives SAGs concurrent-enforcement powers and concluding that " $[\mathrm{t}]$ his language suggests that Attorneys General will be able to step into the shoes of the Bureau in enforcing Federal consumer financial protection law, with the same investigatory tools and remedies that are available to the Bureau").

145. See, e.g., Dodd-Frank Wall Street Reform and Consumer Protection Act: Federal Preemption User Guide, MORRISON \& FOERSTER 13 (July, 2010), http://www.mofo.com/files/Uploads/Images/ 100723 UserGuide.pdf (" $[\mathrm{T}]$ he CFPB defers to the Enumerated Consumer Laws where those laws themselves state when the state attorneys general or state regulators may take enforcement action under those laws.").

146. State Official Notification Rule, 77 Fed. Reg. 39,112, 39,1 13 (June 29, 2012 ). 
issued under this title." 147 The issue concerns the meaning of "provisions of this title" and likewise the meaning of "regulations issued under this title." ${ }^{8} 8$ Without question these two phrases encompass Title X's new UDAAP prohibition and any regulations the CFPB promulgates under it, as well as a few other provisions in Title $\mathbf{X}$ where Congress created new regulatory powers and placed them in the hands of the CFPB. ${ }^{149}$

Nonetheless, in at least two ways Title $\mathrm{X}$ reaches into the pre-existing structure of federal consumer financial protection. First, in Title X Congress transferred administrative responsibility for most existing consumer financial protection laws to the CFPB..$^{15^{\circ}}$ Second, and more important, in Title $\mathrm{X}$ Congress announced two prohibitions that encompass the federal, substantive norms that protect consumers in the financial marketplace. In a brief section captioned "Prohibited Acts," Congress stated:

It shall be unlawful for any covered person or service provider-

(A) to offer or provide to a consumer any financial product or service not in conformity with Federal consumer financial law, or otherwise commit any act or omission in violation of a Federal consumer financial law; or

(B) to engage in any unfair, deceptive, or abusive act or practice. ${ }^{151}$

On the basis of this first prohibition, Congress empowered SAGs to enforce the whole of federal consumer financial law and any regulations under those laws, with the only exception being the limitation on enforcing only regulations against federal depositories. ${ }^{15^{2}}$ The first prohibition does not render any acts unlawful that did not already have that status. Congress created a provision in Title $\mathrm{X}$ that expressly prohibited acts already unlawful under the laws and regulations subsumed within the definition of "federal consumer financial law." This prohibition is one of the "provisions of this title" that Title X empowers SAGs to enforce. ${ }^{153}$

Arguments in support of the narrow reading are not convincing. One possible argument looks to the definition of "federal consumer financial law" and concludes that the statute distinguishes between "provisions of this

\footnotetext{
147. 12 U.S.C. $\$ 5536(a)(1)$.

148. Id. $\$ 555^{2(a)(1) . ~}$

149. See supra note 139 .

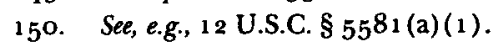

151. Id. $\$ 5536(\mathrm{a})(1)$.

152. The second prohibition is arguably included within the first, insofar as Congress defined "federal consumer financial law" to include "the provisions of this title," of which UDAAP is clearly a provision. Id. $\S 5481$ (14).

153. Id. $\$ 555^{2}(\mathrm{a})(1)$.
} 
title" and "the enumerated consumer laws." 154 Accordingly, this distinction supports the claim that "provisions of this title"-the same language used later in Title $X$ to describe the scope of SAG enforcement powers ${ }^{155}$-does not include the eighteen federal laws which the statute calls the "enumerated consumer laws," and any rules under those laws. ${ }^{6} 6$ This argument would have more weight if the only way Congress extended the reach of Title $X$ to the already-existing structure of federal consumer financial protection was to transfer administrative responsibility for these pre-existing statutes. However, Congress announced two express prohibitions in Title $\mathrm{X}$, the first of which is a prohibition on violating federal consumer financial law, the second of which is the UDAAP ban. If the second prohibition is a "provision[] of this title" for purposes of section $104^{2}$, then so is the first prohibition. 157

Another argument focuses on the "rule of construction" in section 1042 that follows the grant of enforcement power to states. This rule states: "No provision of this title shall be construed as modifying, limiting, or superseding the operation of any provision of an enumerated consumer law that relates to the authority of a State attorney general or State regulator to enforce such Federal law." ${ }_{15}^{8}$ Prior to the Dodd-Frank Act, a few federal statutes gave states limited concurrent-enforcement powers. ${ }^{159}$ If the broad reading prevails, the argument goes, then the rule of construction is nonsensical because this interpretation only expands the powers of states to enforce these other statutes. Under the narrow reading, however, this rule functions to make clear that states are not limited to enforcing UDAAP, but retain these other previous grants of concurrent-enforcement powers.

The broad view, however, makes sense of this rule of construction when read against the restriction in the previous paragraph limiting SAGs to enforcing only regulations and not statutory provisions against federal depositories. ${ }^{160}$ The rule of construction makes clear that in those past or future instances where the enumerated consumer laws allow SAGs to enforce provisions of those laws against federally chartered depositories, that power is not superseded by the restriction in Title $\mathrm{X}$ on states prohibiting the enforcement of the statutory provisions-namely, UDAAP and the enumerated consumer laws-against such depositories. For example, the rule of construction would make clear that the $198_{3}$ amendment to RESPA giving state attorneys general power to enforce the statute's anti-kickback

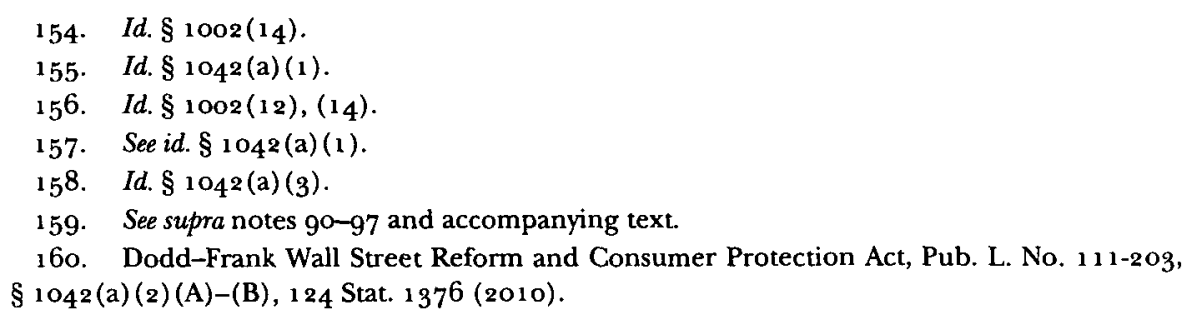


provision against all financial institutions is not overruled. ${ }^{161}$

Although the text of Title $\mathrm{X}$ alone supports the broad reading, the legislative history reinforces this interpretation. Congress never directly discussed the issue, but it did arise in a Senate debate over competing amendments. ${ }^{162}$ Senator Bob Corker (Tennessee) sought to amend Title X to preclude any role for state attorneys general, whereas Senator Tom Carper (Delaware) introduced an amendment that would preserve this power. Speeches on the floor all suggested that the Carper amendment would allow SAGs power to enforce the enumerated consumer laws and the rules passed under these laws. ${ }^{163}$

If the broad reading is correct, this interpretation endows states with considerable power to enforce federal law. To sense the breadth of this power, consider three areas where state attorneys general can enforce federal rules, including against national banks and federal savings associations. ${ }^{164}$ One area is federal disclosure requirements in the provision of consumer credit. The rules fall under Regulation $\mathrm{Z}$, implementing TILA. ${ }^{16}$ These wide-ranging rules "promote the informed use of consumer credit by requiring disclosure about its terms and cost[s]," and also by regulating the substantive terms of credit. ${ }^{166}$ Included are rules governing credit cards, as to their terms, costs, and means of solicitation, ${ }^{167}$ and special rules governing the marketing of credit cards to college students. ${ }^{168}$ Regulation $\mathrm{Z}$ also covers disclosure as to home mortgages ${ }^{169}$ and private

161. See supra note 92 and accompanying text.

162. See 156 CONG. REC. S3866-99 (2010).

163. See, e.g., id. at $\mathrm{S}_{3} 871$ ("[Sen. Corker:] But what has happened as a result of the bill is the fact that ... we now have State AGs-they are going to enforce . . rules that emanate from these Federal statutes.").

164. On the broad reading of the statute, SAGs can enforce any violation of "Federal consumer financial law." As defined, this body of law includes regulations under Title X or the enumerated consumer laws only insofar as they are "prescribed by the Bureau." Dodd-Frank Act $\S 1002$ (14). Although the CFPB has rulemaking power as to most of the rules it enforces, Title X creates some exceptions. The CFPB can enforce several FTC rules, for example. See Identification of Enforceable Rules and Orders, 76 Fed. Reg. 43,569, 43,570 n.1 2 (July 21 , 2011 ) (listing all the rules that the CFPB can enforce, as required by $\$ 106_{3}(\mathrm{i})$ ); CONSUMER Fin. Prot. Bureau, CFPB Supervision AND Examination MaNual Version 2.0 (2012), available at http://www.consumerfinance.gov/guidance/supervision/manual. Presumably the states cannot enforce these rules because the CFPB lacks rulemaking power.

165. Truth in Lending (Regulation Z), 12 C.F.R. $\$ \S 226.1-59$ (2013).

166. Id. $\$ 226 . \mathrm{I}(\mathrm{b})$.

167. Id. $\$ \S 226.5^{-.16}$.

168. Id. $\$ \S 226.5^{1-.59}$.

169. Id. $\$ \$ 226.17^{-24}$. 
educational lending, ${ }^{170}$ which have been issues of increasing interest to state attorneys general. ${ }^{171}$

Another area where states have new powers under federal law concerns the use of debit cards and gift cards, under Regulation E, which implements the Electronic Fund Transfers Act. ${ }^{172}$ Among other functions, these rules require notice to the consumer when an ATM withdrawal incurs a fee ${ }^{173}$ and also the terms under which gift cards expire. ${ }^{174}$ Finally, Title X gives SAGs new federal powers to stop discriminatory lending. Regulation $B^{175}$ falls under the Equal Credit Opportunity Act and creates a broad prohibition on discrimination in the offering of credit on the basis of race, color, religion, national origin, sex, or marital status, ${ }^{176}$ as well as source of income in some cases. ${ }^{177}$

\section{New Substantive Limits on Mortgage Terms}

In addition to empowering state attorneys general to enforce the new UDAAP ban, as well as most federal statutes that protect consumers in the financial marketplace, the Dodd-Frank Act also gives states power to enforce several new substantive limits on mortgage originators and servicers as amendments to TILA. ${ }^{17^{8}}$ These new limits address several of the predatory lending practices that helped fuel the economic crisis and include: a prohibition on steering:179 requiring creditors to make a good faith determination that a borrower has the ability to repay the loan; ${ }^{180}$ a prohibition on certain prepayment penalties; ${ }^{181}$ requirement of escrow accounts for certain loans; ${ }^{182}$ creation of standards to assure appraisal independence; ${ }^{18_{3}}$ requirement for prompt crediting of home loan payments; ${ }^{184}$ requirement for prompt notice of payoff amounts of a home

170. See, e.g., Kelly Field, Attomeys General Take Aim at For-Profit Colleges' Institutional Loan Programs, CHRON. HighER EDUC. (March 20, 2012), http://chronicle.com/article/AttorneysGeneral-Take-Aim-at/ $131254 /$.

171. See 12 C.F.R. $\$ \S 226.4^{6-.48 .}$

172. Electronic Fund Transfers (Regulation E), 12 C.F.R. $\$ \S 205 \cdot 1-20$.

173. Id. $\$ 205.16$.

174. Id. $\S 205.20(\mathrm{e})$.

175. Equal Gredit Opportunity Act (Regulation B), 12 C.F.R. $\$ \S 202.1-17$.

176. 15 U.S.C. $\$ 1691$ (a) (1) (2006).

177. Id. \$1691(a)(2).

178. Dodd-Frank Wall Street Reform and Consumer Protection Act, Pub. L. No. 111-203, $\S 1422,124$ Stat. 1376,2157 (2010).

179. Id. \$1403.

180. Id. \$ $14^{11(a)(2) . ~}$

181. Id. $\$ 1414(\mathrm{a})$.

182. Id. \$1461(a).

183. Id. \$ $147^{2}(\mathrm{a})$.

184. Id. $\S 14_{4}^{6(a)}$. 
loan upon request; ${ }^{185}$ and creation of heightened appraisal requirements in the case of certain higher-risk mortgages. ${ }^{186}$ In each instance, Congress gave SAGs power to enforce both the statutory provision and any rules the CFPB might promulgate under these provisions. ${ }^{187}$ Moreover, this grant includes authority to enforce these provisions against federally chartered depositories. ${ }^{188}$

\section{B. PROCEDURAL AND REMEDIAL POWERS}

The states' ability to exercise these substantive powers to protect consumers of financial products will depend in significant part on the scope of the procedural and remedial powers that accompany them. Although the Act gives some guidance, for the most part it is silent on these powers. Rather, we must discern them against the backdrop of constitutional, statutory, and common law powers that shape the offices of state attorneys general. Using this approach, I will examine the power to investigate, forum selection and multi-state litigation, the use of outside counsel, and various remedies.

\section{Investigation}

Authority to enforce federal law will often be useless without powers to investigate potential wrongdoing. ${ }^{189}$ All SAG offices have a system for receiving consumer complaints, which often serves as the starting point for later enforcement actions. ${ }^{190}$ These systems, and especially the more sophisticated online programs, allow law enforcement to discern trends over time or quickly respond as needed. The decision to bring an enforcement action, however, will often require more evidence than provided in consumer complaints and so the ability to enforce rests on the ability to investigate.

States clearly have power to investigate state law violations. State UDAP laws, for example, generally give SAGs power to investigate and engage in

185. Id. $\$ 1464(\mathrm{~b})$.

186. Id. \$1471.

187. See id. $\$ 14^{22}$ (amending 15 U.S.C. $\$ 1640(e)$ to read, "An action to enforce a violation of [the new statutory provisions] may also be brought by the appropriate State attorney general").

188. Id. $\$ 104^{2}(\mathrm{a})(3)$.

189. See State ATtorneys General. POWER AND ResPonsibilities 234-35 (Emily Myers \& Lynne Ross eds., $2 \mathrm{~d}$ ed. 2007) ("Thorough investigation is the key to the successful prosecution of any consumer case. Accordingly, one of the most effective statutory tools available to most Attorneys General is the authority to serve subpoenas and obtain discovery prior to the filing of any complaint. This enables enforcement authorities to determine whether further action is necessary to enforce the consumer protection laws."); Prentiss Cox, Regulatory Perspectives $\mathcal{E}^{\circ}$ Initiatives: State Attorneys General Case Selection and Investigation, in $12 \mathrm{TH}$ ANNUAL CONSUMER FINANCIAL SERVICES LITICATION INSTITUTE 83 (2007).

19o. Cox, supra note 189 , at 86 . 
pre-complaint discovery, often through issuance of a civil investigative demand ("CID"). ${ }^{191}$ Other state laws provide general authority for a SAG to investigate possible violations of state law. ${ }^{192}$ CID or other investigative authority, however, does not necessarily include the power to pursue precomplaint investigations based on possible violations of federal law. Therefore, many attorneys general will face concerns about the extent of their power to investigate potential federal violations of Title $\mathrm{X}$.

One possibility is that SAGs share in the grant of investigative power given the CFPB under Title X.193 This grant includes broad authority to issue CIDs and seek judicial enforcement.194 The statute, however, does not support this interpretation. Title $\mathrm{X}$ expressly grants this power to "the Bureau," without mentioning that state attorneys general share in it. ${ }^{195}$ Moreover, the authorization for states to enforce federal law in section 1042 does not mention the power to investigate, even though it does mention remedial powers. ${ }^{196}$ In other instances when Congress meant to give states investigative powers, it made its intentions clear.197 Nothing in Title X, however, prohibits SAGs from making investigative demands on the basis of an independent state power to investigate violations of federal law.

Although the availability of the demand power varies among the states, this authority can arise from several sources. A few states give their attorney general broad statutory authority to make investigative demands whenever necessary to protect the public interest. The California Attorney General, for example, has authority to "make investigations and prosecute actions concerning ... [a]ll matters relating to the business activities and subjects under the jurisdiction of the department."198 This authority includes power to demand documents, other materials, or testimony pertinent to an investigation, prior to filing a civil or criminal complaint. ${ }^{199}$ Presumably this broad language would cover investigations pursuant to enforcement actions under Title X.

Although less tested, arguably state attorneys general in most states also have authority to issue CIDs under state common law. With a few exceptions, the states have widely recognized that the powers of this office are

191. CARTER \& SHELDON, supra note $134, \S 13 \cdot 3$.

192. See, e.g., MINN. STAT. $\$ 8.31$, subdiv. 2 (2013).

193. See WALl STREet REForm AND CONSUMER PROTECTION ACT: SUMMARY FOR ATTORNEYS GENERAL, supra note 144 , at 6-8.

194. Dodd-Frank Wall Street Reform and Consumer Protection Act, Pub. L. No. 111 1-203,

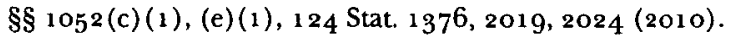

195. Id. $\$ 105^{2}$ (c) (1); see also Rules Relating to Investigations, 76 Fed. Reg. 45,168, 45,1 71

(July 28, 2011 ) (describing authority under $\$ 1080.4$ ).

196. Dodd-Frank Act $\$ 10_{4}^{2}(\mathrm{a})$ (1).

197. See, e.g., S.A.F.E. Mortgage Licensing Act of 2008, 12 U.S.C. $\$ 5^{114}$ (Supp. II 2008 ).

198. CAL. GOV'T CODE $\$ 11180$ (West 2005).

199. Id. \$11181. 
determined not only by state statutory and constitutional law, but also by the common law and the historic powers attached to the office. ${ }^{200}$ Most authorities suggest that SAGs have common law power to issue civil investigative demands. ${ }^{201}$ For example, in People $v$. Crawford the Illinois Supreme Court considered a challenge to the power of the state attorney general to issue civil subpoenas in an antitrust investigation.202 The defendants argued that such power was inconsistent with the state constitution and the organic statute creating the office. ${ }^{203}$ The court denied the challenge, holding in part "that the powers and duties of the Attorney General include not only those powers conferred upon him by statute, but also those powers and duties inherent in the office as it existed at common law," including the power to investigate. ${ }^{204}$

Finally, an attorney general may also have powers to engage in precomplaint discovery on the basis of an express state provision granting power to investigate violations of federal law. Few states have taken this route, but given the sweeping changes brought by the Dodd-Frank Act, more states may want to consider this approach. For example, the State of Washington gives its attorney general power to issue a CID and petition for judicial enforcement of the demand prior to instituting a civil action whenever relevant to an investigation of a possible violation of the state UDAP law "or federal statutes dealing with the same or similar matters that the attorney general is authorized to enforce." 205 The Washington statute models a possible legislative fix to the problem.

200. STATE ATTORNEYS GENERAL, supra note 189 , at $33-38$ (summarizing common law authority and collecting cases). Perhaps the most oft-cited case for this authority is Florida ex rel. Shevin v. Exxon Corp. $5^{26}$ F.2d 266, 268-69 (5th Cir. 1976) ("[T] he attorneys general of our states have enjoyed a significant degree of autonomy. Their duties and powers typically are not exhaustively defined by either constitution or statute but include all those exercised at common law. There is and has been no doubt that the legislature may deprive the attorney general of specific powers; but in the absence of such legislative action, he typically may exercise all such authority as the public interest requires." (citations omitted)). A few states have rejected any common law powers for the office of attorney general. See, e.g., Blumenthal v. Barnes, 804 A.2d 152,169 (Conn. 2002) (" $[\mathrm{W}] \mathrm{e}$ conclude that the office of the attorney general possesses only that common-law authority previously held by the state's attorneys that the legislature has transferred to that office by way of legislation."); In re Estate of Sharp, 217 N.W.2d $25^{8,} 262$ (Wis. 1974).

201. See Widman, supra note 4, at 195 n.156. But see NAT'L Ass'N Of ATTORNEYS GEN., THE OFFICE OF ATTORNEY GENERAL 55 (1971) (finding no express power in the common law to issue subpoenas); STATE ATTORNEYS GENERAL, supra note 189 , at 44 (commenting on aforementioned work and concluding, " $[\mathrm{m}]$ odern courts, however, have analyzed challenges to an Attorney General's authority, not by cataloguing ancient prerogatives, but by focusing on the principles that define the scope of the Attorney General's duty to represent the public interest").

202. People v. Crawford Distrib. Co., 291 N.E.2d 648 (IIl. 1972).

203. Id. at $6_{5} 6$.

204. Id.

205. WASH. REV. CODE ANN. $§ 19.86 .110(1)$ (West 2013 ). 
Any state power to investigate violations of federal consumer financial protection law by national banks, however, is tempered by a provision in Title X that codifies the Supreme Court's holding in Cuomo v. Clearing House Ass'n. ${ }^{206}$ Cuomo involved the scope of a provision in the National Bank Act which prohibits states from exercising "visitorial powers" upon national banks. ${ }^{207}$ The OCC interpreted this provision to block states from bringing any enforcement actions against national banks, including under otherwise non-preempted general state laws governing property, taxation, zoning, and tort law. ${ }^{208}$

On the one hand, Cuomo was a victory for the authority of state attorneys general, striking down the agency's regulation as far exceeding the scope of "visitorial powers" in the statute and affirming the power of states to enforce their general laws against national banks. ${ }^{209}$ On the other hand, the Court made clear that the National Bank Act's prohibition on the exercise of visitorial powers reaches some uses of pre-complaint discovery by a state attorney general. In Cuomo the New York attorney general issued investigative demands against several national banks before filing civil charges.210 The attorney general said the demands were "in lieu of other action," namely the issuance of a subpoena under state law granting such authority. ${ }^{211}$ The Court suggested that if a state attorney general was filing a civil suit, the demand would be legitimate because the enforcement of state law is separate from the exercise of visitorial powers. However, the Court concluded an attorney general could not compel discovery against a national bank absent a direct connection to a law enforcement action, ${ }^{212}$ but could only do so through the judicial process.213 Cuomo would seem to prevent attorneys general from engaging in pre-complaint discovery outside the judicial process against national banks as an effort to determine whether or not to file a law enforcement action.

\section{Forum Selection and Multi-State Litigation}

Title $\mathrm{X}$ authorizes a state attorney general to bring a civil action "in any district court of the United States in that State or in State court that is

206. Dodd-Frank Wall Street Reform and Consumer Protection Act, Pub. L. No. 111 -203, \$ 1047,124 Stat. 1376, 2018 (2010) (codifying Cuomo v. Clearing House Ass'n, 557 U.S. 519 $(2009))$.

207. 12 U.S.C. $\$ 484$ (a) (2006).

208. Bank Activities and Operations; Real Estate Lending and Appraisals, 69 Fed. Reg. 1904 (Jan. 13, 2004) (codified at 12 C.F.R. pts. 7, 34).

209. Cuomo, 557 U.S. at $535-36$.

210 . Id. at 522-23.

211 . Id. at $53^{6 .}$

212. Id.

213. Id. at $53^{\circ}-31$. 
located in that State and that has jurisdiction over the defendant." ${ }_{14}$ Unlike most other provisions granting states power to enforce federal law, Title X allows a state attorney general to file in either state or federal court.. ${ }^{215}$ State attorneys general often prefer to litigate in state court, if only for the perceived advantage of being the chief legal officer in the sovereign's courts. On account of the removal power, however, these actions may often move to federal court. ${ }^{216}$

Nonetheless, although many of the federal procedural rules follow state law, the ability to bring an action in federal court may have a few advantages. In a narrow set of circumstances, a federal forum may give an attorney general power to reach persons otherwise beyond the reach of state courts. Even among states whose long-arm statutes reach as far as the Constitution permits, ${ }^{217}$ the Due Process Clause of the Fourteenth Amendment still requires minimal contacts with the particular state. ${ }^{218}$ In most cases, the personal jurisdiction of a federal district court extends only as far as the same power granted to state courts in which the federal district lies. ${ }^{219}$ Although the Federal Rules of Civil Procedure recognize a court's jurisdiction over persons beyond the bounds of state law where a federal statute creates nationwide service of process, ${ }^{220}$ Congress did not give federal

\footnotetext{
214. Dodd-Frank Wall Street Reform and Consumer Protection Act, Pub. L. No. 11 1-203, § 1042 (a) (1), 124 Stat. 1376, 2012 (2010).

215. Id.; see Lemos, supra note 4 , at 708 ("Most state-enforcement provisions specify that state attorneys general must sue in federal court, thereby departing from the default presumption that state courts retain concurrent jurisdiction over federal causes of action." (citations omitted)); id. at 708-10 nn.41-54.
}

216 . See 28 U.S.C. $\$ 133_{1}$ (2006) (federal question jurisdiction); 28 U.S.C. $\$ 1441$ (a) (2006) (removal power); Dodd-Frank Act $\$ 1042$ (b) (2) (CFPB power to intervene and remove an action to federal court).

217. See 4 Charles Alan Wright \& Arthur R. Miller, Federal Practice and Procedure $\S 1068$ n.12 (3d ed. 2002 ).

218 . See International Shoe Co. v. Washington, 326 U.S. 310,316 (1945) (“[D]ue process requires only that in order to subject a defendant to a judgment in personam, if he be not present within the territory of the forum, he have certain minimum contacts with it such that the maintenance of the suit does not offend traditional notions of fair play and substantial justice." (internal quotation marks omitted)).

219. FED. R. CIV. P. $4(\mathrm{k})(1)(\mathrm{A})$.

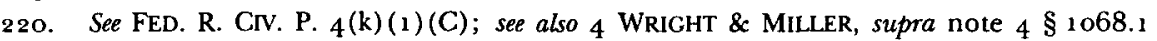
("Rule $4^{(k)(1)(D)}$ [now ${ }_{4}(k)(1)(C)$ ] of the 1993 amendments now makes clear that when Congress authorizes personal jurisdiction over a defendant service may be made in accordance with the federal statute. ... The power of Congress to authorize nationwide service of process in actions arising under federal law is beyond question, as a line of venerable Supreme Court cases have stated." (footnotes omitted)). Common federal statutes that carry a nationwide service of process provision include the Securities Exchange Act of 1934,15 U.S.C. $\$ \$ 77$ aa, 78 aa (20o6) (securities fraud); the Clayton Act, 15 U.S.C. $\$ 22$ (2006) (antitrust actions); Employee Retirement Income Security Act, 29 U.S.C. $\$ 1132$ (e)(2) (2006) (ERISA actions); and Federal Debt Collection Procedures Act, 28 U.S.C. $\$ 3004$ (b) (2006). 
courts this power under Title X. ${ }^{221}$ The Rules, however, do recognize a district court's power over a foreign defendant who falls beyond the reach of any state's courts and the Constitution does not otherwise preclude personal jurisdiction. ${ }^{222}$ In this case, the Due Process Clause of the Fifth Amendment applies and only requires that the defendant have minimal contacts with the United States as a whole, rather than a particular state as the Fourteenth Amendment demands. ${ }^{23}$

In most cases, a defendant will fall within the personal jurisdiction of some state and therefore the federal long-arm provision will not apply. These situations will leave SAGs with the same limitations as to personal jurisdiction they face under state law, since Title $\mathrm{X}$ permits them to file only in a federal district court "in that State." ${ }_{24}$ Nonetheless against some defendants, especially foreign internet operators beyond the reach of a state's long-arm statute, the availability of a federal forum may allow a case to go forward. ${ }^{225}$

In addition to possibly extending the scope of personal jurisdiction, a Title $\mathrm{X}$ action in federal court will often give SAGs increased discovery powers to reach persons out of state. Beginning with its decision in Intermational Shoe, the Supreme Court opened the door for states to empower their courts to reach out-of-state defendants. ${ }^{226}$ The revolution in personal jurisdiction, however, never advanced to expand a state court's discovery powers in a civil action. ${ }^{227}$ In many states still today, inter-state discovery is slow, cumbersome, and often fails to deliver. The process can involve several

221. State attorneys general must file "in any district court of the United States in that State or in State court that is located in that State." Dodd-Frank Act $\$ 10_{4} 2$ (a) (1). CFPB must file "in a United States district court or in any court of competent jurisdiction of a state in a district in which the defendant is located or resides or is doing business." Id. $\$ 1054$ (f).

222. FED. R. CIV. P. 4 (k) (2).

223. See Notes of Advisory Committee on Rules-1993 Amendment to FED. R. CIV. P. $4(k)(2), 28$ U.S.C. Appendix (2006) (recognizing Fifth Amendment limitation "that any defendant have affiliating contacts with the United States"). The courts of appeal have upheld this application of the Fifth Amendment. See, e.g., Synthes (U.S.A.) v. G.M. Dos Reis Jr. Ind. Com. De Equip. Medico, 563 F.3d 1285, 1295 (Fed. Cir. 2009) ("[T] he due process analysis ... contemplates a defendant's contacts with the entire United States . . . ."); Holland Am. Line Inc. v. Wärtsilä N. Am., Inc., $48_{5}$ F.3d 450, 462 (9th Cir. 2007) (same); Mwani v. bin Laden, 417 F.3d 1, 11 (D.C. Cir. 2005) (same); Cent. States, Se. \& Sw. Areas Pension Fund v. Reimer Express World Corp., 230 F.3d 934, 946 (7th Cir. 2000) (same).

224. Dodd-Frank Act $\$ 10_{42}$ (a) (1).

2 25. Plaintiffs have primarily used Rule $4(k)(2)$ to reach foreign internet operators to raise intellectual property claims. See, e.g., Synthes, $5^{63}$ F.3d 1285 at $1293-96$; Graduate Mgmt. Admission Council v. Raju, 241 F. Supp. 2d 589, 596-60o (E.D. Va. 2003); Sunshine Distrib. v. Sports Authority Mich., 157 F. Supp. 2d 779, 787-90 (E.D. Mich. 2001); see also Mark B. Kravitz, National Contacts and the Internet: The Application of $F R C P P_{4}(k)(2)$ to Cyberspace, 7 U. BALT. INTELL. PROP. L.J. 55, 56 (1998).

226. Int'l Shoe Co. v. Washington, 326 U.S. 310 (1945).

227. See Rhonda Wasserman, The Subpoena Power: Pennoyer's Last Vestige, 74 MINN. L. REV. 37 , $74-75(1989)$. 
months of seeking court approval in both the trial state and the discovery state, and in some jurisdictions having to hire local counsel in the discovery state. ${ }^{28}$ Under Rule 45 , however, a federal plaintiff can issue a subpoena in the name of the court in the discovery state without ever going before a court. ${ }^{22}$ If necessary, the plaintiff can petition the federal court in whose name the subpoena was issued to enforce the order..$^{23^{\circ}}$ Although the gradual adoption by states of the Uniform Deposition and Discovery Act has reduced the burden of state discovery, nearly half the states have not yet adopted the Act and the federal process remains simpler. ${ }^{231}$

The forum provision in section 1042 (a)(1) also has implications for bringing multi-state actions to enforce federal consumer financial law. ${ }^{292}$ While subject to criticism, these actions have been a powerful tool in the hands of state attorneys general, starting in the 1980 s and rapidly accelerating in the 1990 s with the tobacco litigation.933 In multi-state litigation, attorneys general pool their resources to file similar complaints in state court or one complaint as joint-plaintiffs in federal court. ${ }^{234}$ The language in Title $\mathrm{X}$ granting concurrent-enforcement powers precludes the latter form of coordination, since state attorneys general can only bring a civil action in state court or "in any district court of the United States in that State." 235 Unless a state can satisfy the personal jurisdiction requirement in a state or federal court located within its borders, SAGs cannot enforce federal consumer protection laws that involve violations in other states. Although some observers have argued to the contrary, ${ }^{296}$ this restriction does not close the door to coordination. The states could file similar complaints in state court, as happened in 2000 when twenty-seven states filed separate state

228. See id. at $115,120-23$.

229. FED. R. CIV. P. 45(a) (3); see also FED. R. CIV. P. 45 (a) (3) advisory committee's note to 1991 Amendment ("In authorizing attorneys to issue subpoenas from distant courts, the amended rule effectively authorizes service of a subpoena anywhere in the United States by an attorney representing any party.").

23o. See FED. R. Civ. P. 45 (e).

231. See INTERSTATE DEPOSITIONS AND DISCOVERY ACT (2007), available at http://www.uniform laws.org/Act.aspx?title=Interstate\%2oDepositions\%2oand\%2oDiscovery\%2oAct.

232. Dodd-Frank Wall Street Reform and Consumer Protection Act $\$ 1042(a)(1)$, Pub. L. No. 11-203, 124 Stat. 2012 (2010).

233. See Cornell W. Clayton, Law, Politics and the New Federalism: State Attorneys General as National Policymakers, 56 REV. POLS. 525, 531-38 (1994) (describing the increasingly political role of state attorneys general); Jason Lynch, Federalism, Separation of Powers, and the Role of State Attomeys General in Multistate Litigation, 101 CoLUM. L. REV. 1998, 2003-08 (2001); Timothy Meyer, Federalism and Accountability: State Attomeys General, Regulatory Litigation, and the New Federalism, 95 CALIF. L. REV. 885, 899-904 (2007).

234. See Lynch, supra note 233, at 2003-08; Kevin J. O'Connor, Is the Illinois Brick Wall Crumbling?, 15 ANTITRUST 34, 35-36 (2001).

235. Dodd-Frank Act $\$ 1042$ (a) (1) (emphasis added).

236. Lemos, supra note 4 , at 763 (concluding that section $10_{4}^{2}$ (a) (1) of the Dodd-Frank Act "effectively precludes states from pooling their resources in multistate actions"). 
claims accusing Publishers Clearing House of deception in their sweepstakes promotion. ${ }^{237}$ Alternatively, the states could file separate actions in federal court, with the likelihood that the judicial panel on multidistrict litigation would consolidate the cases in one district court.998 Although the states would lose the opportunity to select a perceived favorable forum, they would retain the efficiencies of coordinated litigation.

\section{Outside Counsel}

Title $\mathrm{X}$ also raises the question of whether state attorneys general can hire outside counsel on a contingency-fee basis to enforce federal law. The employment of plaintiffs' attorneys under the supervision of state attorneys general has a long history, but entered the spotlight with the tobacco litigation of the mid-19gos. Supporters of the practice argue that hiring outside counsel provides necessary resources for attorneys general who may lack funding and expertise to bring critical enforcement actions on their own, while critics argue that these arrangements skirt the state legislature's appropriations oversight, lack transparency, often fall in the hands of political donors, and may lead to over-enforcement. 239

Title $X$ is silent on whether SAGs can employ outside counsel, and thereby implicitly permits this arrangement, assuming state law otherwise allows. In other instances, when Congress intended to limit how a state attorney general enforces federal law it has expressly prohibited the hiring of private counsel on a contingency-fee basis. ${ }^{2} 4^{\circ}$ Moreover, although a

237. See Publishers Clearing House Strikes Deceptive-Practices Accord, N.Y. TIMES (Aug. 23, 2000), available at http://www.nytimes.com/200o/o8/23/us/publishers-clearing-house-strikes-deceptivepractices-accord.html. In a federal action, the cases may be subject to removal by the defendant or the CFPB.

$23^{8}$. 28 U.S.C. $\$ 1407$ (2006) (multidistrict litigation).

239. See David A. Dana, Public Interest and Private Lawyers: Toward a Normative Evaluation of Parens Patriae Litigation by Contingency Fee, 51 DEPAUL L. REV. 315, 315 (2001); Donald G. Gifford, Impersonating the Legislature: State Attorneys General and Parens Patriae Product Litigation, 49 B.C. L. REV. 913, 964-69 (2008); Myriam Gilles \& Gary Friedman, After Class: Aggregate Litigation in the Wake of AT\&T Mobility v. Concepcion, 79 U. CHI. L. REV. 623, 658-75 (2012); Victor E. Schwartz \& Christopher E. Appel, The Plaintiffs' Bar's Covert Effort to Expand State Attorney General Federal Enforcement Power, WASH. LEGAL FOUND. LEGAL BACKGROUNDER, July 10, 2009, at 4. For an overview of how some states are responding to this issue see Amanda Bronstad, AGs Review Hiring of Outside Counsel, LAW.COM (May 15, 2007), http://www.law.com/ jsp/article.jsp?id=1179146390047. In early 2012 , the House of Representatives held a hearing on the use of contingency fees in the state enforcement of federal law, which included testimony from Professor Amy Widman (Assistant Professor of Law, Northern Illinois University), Hon. William McCollum, Jr. (former Florida attorney general), and James $\mathbf{R}$. Copland (Director and Senior Fellow, Center for Legal Policy, Manhattan Institute for Policy Research). Contingent Fees and Conflicts of Interest in State AG Enforcement of Federal Law: Hearing Before the Subcomm. on the Constitution of the H. Comm. on the Judiciary, 112th Cong. (2012) [hereinafter Contingent Fees Hearing].

240. As early as 1976, with passage of the Hart-Scott-Rodino Antitrust Improvement Act granting concurrent-enforcement powers to SAGs, Congress was careful to define "state 
presidential executive order bans hiring of outside counsel by contingency fee, the order applies only to "individuals that provide such services to or on behalf of the United States." ${ }^{41}$

\section{Remedies}

Title $\mathrm{X}$ creates a broad range of remedies, all of which are available to state attorneys general enforcing the statute. ${ }^{24^{2}}$ The statute begins with an umbrella provision that empowers courts "to grant any appropriate legal or equitable relief with respect to a violation of Federal consumer financial law." ${ }_{43}$ Recall that this last phrase refers to any substantive provisions in Title $\mathrm{X}$, including the general UDAAP ban, as well as any of the eighteen federal consumer financial protection laws ("enumerated consumer laws") and accompanying regulations. ${ }^{244}$ The statute then provides a non-exclusive list of available remedies, including "rescission or reformation of contracts; refund of moneys or return of real property; restitution; disgorgement or compensation for unjust enrichment; payment of damages or other monetary relief; publication notification regarding the violation, including the costs of notification" and limits on the offender's activities or functions. ${ }^{245}$ In addition, the statute creates a three-tiered civil penalty scheme that allows a court to assign penalties as steep as $\$ 1$ million for each day the violation continues. ${ }^{2}{ }^{6}$ The only remedy the statute precludes is punitive damages. ${ }^{247}$ Finally, a state attorney general can recover all costs associated with bringing the case if the state prevails. ${ }^{24}$

Congress's decision to place these remedial powers in the hands of the chief legal officers of the fifty states is significant for at least two reasons. First, these powers allow state attorneys general to seek broad relief on

attorney general" so as to exclude "any person employed or retained on a contingency fee based on a percentage of the monetary relief awarded." Hart-Scott-Rodino Antitrust Improvement Act, Pub. L. No. $94-435, \S 301$, go Stat 1383 (codified as amended at 15 U.S.C. $\S$ $15 \mathrm{~g}(1)(\mathrm{A})(2006))$.

241. Exec. Order No. 13,433, 72 Fed. Reg. 28,441 (May 16, 2007) (emphasis added). Even critics recognize that Title $X$ permits state attorneys general to hire outside counsel on a contingency fee basis, and instead call on Congress to codify Executive Order 13,433 to apply to state attorneys general exercising their powers under the Dodd-Frank Act. See Contingent Fees Hearing, supra note 239, at 49 (testimony of James R. Copland, Director and Senior Fellow, Center for Legal Policy, Manhattan Institute for Policy Research).

242. Dodd-Frank Wall Street Reform and Consumer Protection Act $\$ 104^{2}$ (a) (1), Pub. L. No. 11-203, 124 Stat. 2012 (2010) (authorizing state attorneys general to bring civil actions and empowering them "to secure remedies under provisions of this title or remedies otherwise provided under other law"); id. $\S 1055$ (listing available remedies).

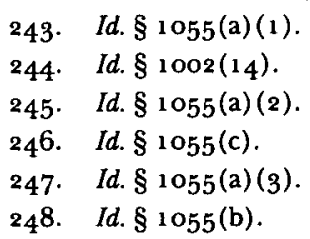


behalf of aggrieved consumers. In effect, Title $\mathrm{X}$ codifies a gloss on the common law doctrine of parens patriae. ${ }^{249}$ This doctrine gives state attorneys general standing ${ }^{25^{\circ}}$ to represent "a set of interests that the State has in the well-being of its populace." ${ }^{51}$ The Supreme Court has described these rights as "quasi-sovereign" interests, which include a state's interest in the health, comfort, economic well-being, and welfare of the state's citizens. ${ }^{25^{2}}$ Examples of quasi-sovereign interests include a state's right to address public nuisances, including nuisances that have direct negative effects on private commerce and public health, ${ }^{253}$ and a state's right to preserve a wellfunctioning marketplace and the economic interests of its citizens, threatened by another state or private enterprise. ${ }^{254}$ As the U.S. Supreme Court has interpreted the common law doctrine, absent an express statutory allowance for standing, a state has standing to bring suit under federal law when at least two conditions prevail: the state has a quasi-sovereign interest, apart from the interests of particular private parties, and a "sufficiently substantial segment of its population" has suffered the harm. ${ }^{255}$ Although courts have varied, the majority position is that under the parens patriae doctrine a state attorney general can seek not only injunctive relief, but also damages on behalf of individual citizens as long as the injury to the state is not merely the injury to the state's citizens. ${ }^{25^{6}}$

249. For background on the common law doctrine of parens patriae, see generally STATE ATTORNEYS General, supra note 189 , at 102-04; Richard P. Ieyoub \& Theodore Eisenberg, State Attorney General Actions, the Tobacco Litigation, and the Doctrine of Parens Patriae, 74 TUL. L. REV. 1859 (200o); Jack Ratliff, Parens Patriae: An Overview, 74 TUL L. REV. 1847 (200o); Jim Ryan \& Don R. Sampen, Suing on Behalf of the State: A Parens Patriae Primer, 86 ILL. B.J. 684 (1998). Although the common law doctrine has evolved over centuries, the most important modern case interpreting the bounds of the doctrine is Alfred L. Snapp EN Son, Inc. v. Puerto Rico ex rel. Barez, $45^{8}$ U.S. $59^{2}$ (1982).

250. Snapp, $45^{8}$ U.S. at 600 .

251. Id. at 602 .

252. Id. at $601,60_{5}-06$.

253. See, e.g., id. at 603-04 (citing Missouri v. Illinois, 180 U.S. 208 (1901) ("Missouri sought to enjoin [Illinois] from discharging sewage [that polluted] the Mississippi River in Missouri")).

254. See, e.g., id. at $60_{5}$ (citing Pennsylvania v. West Virginia, 262 U.S. 553 (1923) (Pennsylvania sought to protect the right "of its residents [to maintain] access to natural gas produced in West Virginia.")).

255. Id. at 607 .

256. See generally Ryan \& Sampen, supra note 249 , at 686-88 (listing key cases). In Maryland v. Louisiana, $45^{1}$ U.S. 725 ( 1981$)$, the Court recognized standing on the grounds of parens patriae for eight states that sued Louisiana because of a tax it imposed on natural gas exports from the state. The Court concluded "A State is not permitted to enter a controversy as a nominal party in order to forward the claims of individual citizens. But it may act as the representative of its citizens in original actions where the injury alleged affects the general population of a State in a substantial way." Id. at 737 . The Court looked to the impact the tax would have on "a great many citizens" and the likelihood that individual consumers would not sue given the small amounts at stake for each person. Id. at 739 . In cases where individual citizens do not have a private right of action, states will be unable to recover on their behalf. See, 
Remedial powers under Title $\mathrm{X}$ are in some ways more generous than the common law doctrine it codifies.257 While the common law doctrine requires a state assert a more general interest than the harms to individual citizens, Title $\mathrm{X}$ expressly gives states power to recover on behalf of its citizens without establishing a quasi-sovereign interest..$^{25}$ Moreover, unlike the common law doctrine, states can recover for citizens regardless of whether the underlying consumer financial protection law contains a private right of action.

Despite the seemingly clear language in section 1055, some early commentators have argued that state attorneys general lack the power to recover on behalf of their citizens. ${ }^{259}$ This argument stems from language originally included in Title $\mathrm{X}$, as introduced in the House, which said that "[a]ny State attorney general may bring a civil action in the name of such State, as parens patriae on behalf of natural persons residing in such State... to secure monetary or equitable relief for violation of any provisions of this title or regulations issued thereunder." ${ }_{260}$ The final language omitted the reference to the common law doctrine. ${ }^{261}$ Although Congress has sometimes included the omitted language to make clear that states can seek relief on

e.g., Satsky v. Paramount Commc'ns, Inc., 7 F.gd 1464, 1469 (1oth Cir. 1993) (concluding that a state suing parens patriae could not assert claims for private damages under CERCLA because the statute did not provide for such damages).

257. Congress has codified the states' power to recover on behalf of their citizens in other more limited contexts. See, e.g., Children Online Privacy Protection Act, 15 U.S.C. $\$ 650^{\circ}$ (a) (1) (20o6); Clayton Act, 15 U.S.C. $\S 15 \mathrm{C}(\mathrm{a})(1)$ (2006) (antitrust); Commodity Exchange Act, 7 U.S.C. $\S 13 \mathrm{a}-2$ (1) (2012) (trading of commodity futures); Controlling the Assault of NonSolicited Pornography and Marketing Act, 15 U.S.C. $\$ 7706$ (f) (2006); Credit Repair Organizations Act, ${ }_{5}$ U.S.C. $\$ 1679 h(c)$ (1) (2006); Freedom of Access to Clinic Entrances Act, 18 U.S.C. $\S 248(\mathrm{c})(3)$ (2006) (access to reproductive health services); Telemarketing and Consumer Fraud and Abuse Prevention Act, 15 U.S.C. $\$ 6103$ (a) (2006); Telephone Disclosure and Dispute Resolution Act, ${ }_{15}$ U.S.C. $\$ 5712$ (a) (2006) (pay-per-call services).

258. Dodd-Frank Wall Street Reform and Consumer Protection Act $\S 104^{2}$ (a) (1), Pub. L. No. 11-203, 124 Stat. 2012 (2010); id. § 1055 (a).

259. See, e.g., Thomas I. Elkind et al., Consumer Financial Protection Act: Preemption Questions, FOLEY \& LARDNER LLP 26 (Aug. 26, 2010), http://www.foley.com/files/Event/ad781 735-c385-475b-8eao0821 79b6669o/Presentation/EventAttachment/b9o104do-oeb6-4b83-a381-oeacbdde3e56/CFPA_ Presentaiton.pdf ("There is no provision permitting state attorneys general to bring class action type cases against any covered entity on behalf of state citizens."); More Than Just Financial Reform: Analysis and Observations on the Dodd-Frank Wall Street Reform and Consumer Protection Act, JONES DAY WHITE PAPER 87 (Aug. 2010), http://www.jonesday.com/files/Publication/d7d 7 lbc5-6ee 4-4144-9aob91 b6d95cb2ag/Presentation/PublicationAttachment/24bcecbc-dc i f-4863-9204-93fdcbgbcc8e/

Financial\%2oReform\%2oDodd-Frank\% 2oWhite\%2oPaper.pdf ("The Act does not however, include the authorization that was part of the original House bill [section 1041] to sue as parens patriae, which could have enabled state authorities to sue for damages incurred by their citizens.").

260. The Wall Street Reform and Consumer Protection Act of 2009, H.R. 4173, 111 th Cong. $\$ 4402$ (a) (1) (emphasis added) (as introduced in the House on Dec. 2, 2009).

261. Dodd-Frank Act $\$ 10_{4}^{2}(a)(1)$ ("[State attorneys general] may bring a civil action in the name of such State ... to enforce provisions of this title or regulations issued under this title, and to secure remedies under provisions of this title or remedies otherwise provided under other law."). 
behalf of their citizens, on many occasions the legislature has codified the common law doctrine without any explicit reference to the doctrine. ${ }^{262}$ Moreover, the list of remedies available-which includes "restitution," "disgorgement or compensation for unjust enrichment," and "payment of damages or other monetary relief"-confirms that states can seek remedies for their citizens. ${ }^{263}$

Congress's decision to place these remedial powers in the hands of state attorneys general is also significant for a second reason: these concurrent powers will often extend well beyond the powers otherwise available under state laws. Most important, the remedial powers available to state attorneys general under Title $\mathrm{X}$ in some cases significantly exceed the same powers available under the state UDAP law. While state law often permits courts to issue injunctions and provides for restitution, few state UDAP statutes include an express, broad allowance to recover for "damages or other monetary relief," as permitted under Title X. ${ }^{264}$ As one consumer advocacy organization has pointed out, this provision "allows for recovery of consequential and other damages exceeding the amount paid for the product or service." ${ }_{26}$ Moreover, other remedies available such as "rescission or reformation of contracts" ${ }_{266}$ are often not available under state law. ${ }^{267}$ Lastly, the civil penalties available under federal law will often far exceed the penalties courts could impose under a state UDAP statute. Rhode Island, for example, does not provide for any civil penalty, and other jurisdictions, such as Pennsylvania and Missouri, only allow for penalties up to $\$ 1$,ooo per

262. Statutes that include an express reference to the common law doctrine include Children Online Privacy Protection Act, ${ }_{5}$ U.S.C. $\$ 65^{\circ} 4(a)(1)$ (2006); Clayton Act, 15 U.S.C. $\S 15 \mathrm{c}(\mathrm{a})(1)$ (2006) (antitrust); Controlling the Assault of Non-Solicited Pornography and Marketing Act, 15 U.S.C. $\$ 7706$ (f) (1) (2006); Freedom of Access to Clinic Entrances Act, 18 U.S.C. $\$ 248$ (c) (3) (A) (2006); and Telemarketing and Consumer Fraud and Abuse Prevention Act, 15 U.S.C. $\$ 6 \log _{3}$ (a) (2006). Several statutes, however, grant the same power without invoking the name of the common law doctrine. See, e.g., Commodity Exchange Act, 7 U.S.C. $\$$ 13 a-2(1) (2012) (trading of commodity futures); Credit Repair Organizations Act, 15 U.S.C. $\$$ $1679 h(c)$ (1) (20o6); Home Ownership and Equity Protection Act, 15 U.S.C. $\$ \S 1640$ (a), (e) (2oo6 \& Supp. III 2009); and Telephone Disclosure and Dispute Resolution Act, 15 U.S.C. $\S$ 5712 (a) (2006) (pay-per-call services).

263. Dodd-Frank Act $\$ 1055$ (a) (2). Proponents of the view that Title X does not codify the parens patriae doctrine also argue that the absence of any express reference to the doctrine has special meaning given that a later provision in Title $\mathrm{X}$ does invoke the common law doctrine. See id. $\$ \S 1097(1)$, (2) (granting state attorneys general the power to bring a civil action "as parens patriae" for "unfair or deceptive acts or practices regarding mortgage loans"). Section 1097 , however, is merely a conforming amendment to a bill that was originally passed into law in 2009. See Omnibus Appropriations Act of 2009, Pub. L. No. 111-8, sec. 430, \$626(b) (1), 123 Stat. 678 .

264. See supra note 143 , at 18 .

265. Id. at 18 .

266. Dodd-Frank Act $\$ 1055$ (a) (2)(A).

267. See CARTER \& SHELDON, supra note 134 , $\$ 12.7 .2$ ("Relatively few state UDAP statutes explicitly provide rescission or voiding the transaction as a remedy."). 
violation. ${ }^{268}$ These low penalties may amount to a slap on the wrist that does little to deter violations of the law. ${ }^{269}$

\section{IMPLEMENTATION}

On paper the Dodd-Frank Act empowers state attorneys general to play a vital role in reforming the American system of consumer financial protection. The gap between paper and practice, however, may be wide. Closing the gap will depend in significant part on implementation, including putting in place systems to support partnering between the states and especially with the CFPB. Before turning to these measures, I briefly mention a few inherent limits on states as co-enforcers and review several implementation steps already underway.

Several factors will likely shape the degree to which individual SAGs exercise these new powers, including resources, ideology, independence, and overlap. Most state attorney general offices have very limited resources and, while attention to consumer protection issues has greatly increased in recent decades, most offices will have very few dedicated attorneys in this area. ${ }^{27^{\circ}}$ The time required to understand Title $\mathrm{X}$ and federal law alone may prohibit action. Moreover, ideology may often shape the readiness of state attorneys general to bring consumer financial protection actions in states where the balance favors industry over consumer protection or political alliances discourage litigation against the financial services industry. ${ }^{27} \mathrm{~A}$ desire to maintain independence may also mitigate the use of these new powers. The separate sovereign identity of states, along with the pressures that shape an office that in most states is elected, may discourage bringing actions under federal law or partnering with a federal agency. Finally, where state laws are adequate, attorneys general may opt to stay in state court where they enjoy the perceived advantage of being the chief legal officer of the sovereign.

At the same time, other factors may encourage states to exercise these new powers. In their empirical study examining the actual use of concurrent-enforcement authority under sixteen federal consumer protection laws, Widman and Cox found that states infrequently exercised

268. See supra notes $13^{1-33}$ and accompanying text.

269. At the same time, the often more generous federal monetary remedies have the potential to skew decision-making, in particular among states that require their consumer protection units to self-fund through litigation or allow such recoveries to augment budget appropriations. See Lemos, supra note 4 , at 734-35.

270. STATE ATTORNEYS GENERAL, supra note 189 , at $23^{8}$ ("Staffing of consumer protection divisions in the offices of the Attorney General varies widely and can range from one attorney with additional responsibilities in other areas to well over a dozen attorneys involved exclusively in consumer protection enforcement.").

271. See Colin Provost, The Politics of Consumer Protection: Explaining State Attmney General Participation in Multi-State Lawsuits, 59 POL. RES. Q. 609, 61 2-1 7 (2006). 
these powers and never used about half the statutes. ${ }^{27^{2}}$ Nonetheless they noted that state attorneys general more often invoked federal statutes that addressed areas where historically the office has been active, such as consumer financial protection. ${ }^{273}$ Moreover, as already mentioned, the federal UDAAP and other enumerated laws will sometimes offer stronger protections than state law. ${ }^{274}$ And depending on the leadership at the CFPB and its willingness to cooperate with states, attorneys general may find that the CFPB offers invaluable federal resources that states lack. ${ }^{275}$

At this point in time, the states and the CFPB have already taken some steps toward implementation. Shortly after Congress passed the Dodd-Frank Act, the National Association of Attorneys General ("NAAG") issued a summary of the Act and its implications for the states. ${ }^{276}$ Moreover, several SAGs and the CFPB have begun building partnerships. In April 2011, the CFPB and a group of state attorneys general now known as the Dodd-Frank Working Group ${ }^{277}$ issued a joint statement outlining broad principles that will guide this partnership. ${ }^{2} 7^{8}$ The NAAG has a standing Consumer Financial Protection Bureau Working Group. ${ }^{279}$ The CFPB has begun to participate in some of the NAAG regular staff-level conference calls on consumer protection issues. Several attorneys general have signed a Memorandum of Understanding ("MOU") with the CFPB to permit information-sharing, while maintaining confidentiality. ${ }^{280}$ Moreover, the California State Assembly even held a lengthy hearing about the implications of the Dodd-Frank Act at the state level, including the work of the state attorney general. ${ }^{281}$ Across the states, however, most attorneys general have done very little to

272. See Widman \& Cox, supra note 4 , at $81-82$.

273. Id. at $83-84$ (explaining that several of the federal statutes SAGs do employ "concern consumer credit and finance, another area of traditional focus by state attorneys general").

274. See supra notes $135-39$ and accompanying text.

275. See discussion infra p. 149.

276. See supra note 144 .

277. This group was originally called the "Presidential Initiative Working Group," and was started by North Carolina Attorney General Roy Cooper during his term as President of the NAAG. Dennis Cuevas, New Consumer Financial Protection Bureau Is Open for Business, NAAG, http:/ /www.naag.org/new-consumer-financial-protection-bureau-is-open-for-business.php (last visited Sept. 20, 2013 ).

278. Press Release, Consumer Fin. Protect. Bureau, Consumer Financial Protection Bureau and National Association of Attorneys General Presidential Initiative Working Group Release Joint Statement of Principles (Apr. 11, 2011 ), available at http://www.consumerfinance.gov/ pressreleases/consumer-financial-protection-bureau-and-national-association-of-attorneysgeneral-presidential-initiative-working-group-release-joint-statement-of-principles/.

279. NAAG Standing Committees, NAT'L ASS'N OF ATTORNEYS GEN., http://www.naag.org/ naag_standing_committees.php (last visited Sept. 20, 2013).

280. See infra note 302 .

281. See The Dodd-Frank Wall Street Reform and Consumer Protection Act: Initial Reactions, Initial Steps, and Likely Impacts: Hearing Before the Assemb. Comm. on Banking E' Fin. and the S. Comm. on Banking $\mathcal{F}^{\circ}$ Fin. Insts., 2011-12 Regular Sess. (Cal. 2011), available at http://abnk.assembly. ca.gov/201 loversighthearings (compact disc of hearings on file with author). 
implement their new powers. Although still early, the states have partnered with the CFPB to bring only a few enforcement actions under Title X. ${ }^{282}$

Developing a clear implementation plan is critical if states are going to help restore an adequate level of consumer financial protection, while avoiding over-enforcement and limiting nonuniformity in federal law. Toward this end, state attorneys general should focus on at least three implementation priorities: assessment, authorization, and cooperation. I briefly mention the first two priorities and then focus on the final and most important task of building partnerships among the states and with the CFPB.

\section{A. ASSESSMENT}

In the past, some concurrent-enforcement powers have likely remained unused in part because the states lacked a clear understanding of the federal tools available to them. ${ }^{28}$ The states should begin by conducting an inventory of their new powers under Title X. Although the scope of these powers is uniform across the states, the impact on each state will depend on the scope of state law and where gaps may lie. In some cases states will have new substantive powers. For example, as mentioned earlier the availability of UDAAP under Title $X$ is an extraordinary new enforcement tool for the Michigan attorney general, given a state supreme court ruling that vitiates the state UDAP ban. ${ }^{28_{4}}$ In addition, states will often have additional procedural and remedial powers.

\section{B. AUTHORIZATION}

In addition to assessing the scope of available powers, state attorneys general should ensure they have the necessary state authorization to exercise

282. In June 2012, the CFPB assisted Kentucky Attorney General Jack Conway and twenty other SAGs in a multi-state investigation of GIBill.com, a website that directed veterans and service members to for-profit colleges by strongly implying that the federal government sponsored the site. See Carter Dougherty, 'GI Bill' Site Called Misleading Closed in Settlement, BLOOMBERG (June 27, 2012, 12:58 PM), http://www.bloomberg.com/news/201 2-o6-27/statecloses-college-lead-generator-aimed-at-military.html. The states finally settled with the parent company under an agreement that shut down the website. Id.; QuinnStreet, Inc., Assurance of Voluntary Compliance, SEC.gov (June 26, 2012), available at http://www.sec.gov/Archives/ edgar/data/1117297/o00119312512284713/d372925dex101.htm (on file with the author). The first joint enforcement action between several states and the CFPB was in December 2012 and targeted a debt-relief service provider that required fees in advance of settling debt, in violation of state and federal law. See Press Release, Consumer Fin. Protect. Bureau, Consumer Financial Protection Bureau and State Partners Obtain Refunds for Consumers Charged Illegal Debt-Relief Fees (Dec. 21,2012 ), available at http://www.consumerfinance.gov/pressreleases/ consumer-financial-protection-bureau-and-state-partners-obtain-refunds-for-consumers-chargedillegal-debt-relief-fees/.

283. See Widman \& Cox, supra note 4 , at 84 (noting that "knowledge about the various examined statutes among state attorneys' general offices" may partially explain the non-use of some powers).

284. See supra notes $127-28$ and accompanying text. 
these powers. They should consider in advance whether they are empowered as a matter of state law to conduct investigations and bring enforcement actions under Title $\mathrm{X}$. In many cases, for political and strategic reasons, the state attorneys general will choose not to question their powers in public, as raising the matter may invite scrutiny. Merely exercising the powers may accrue the necessary legitimacy. Nonetheless, in some states the attorney general may need to consider securing authorization from the state legislature.

Many states will have broad statutory or constitutional grants of power to the office of the state attorney general which may authorize the exercise of concurrent-enforcement powers. Moreover, most states recognize robust common law powers associated with the office. ${ }^{285}$ Nonetheless, a few states have expressly rejected common law powers for the state attorney general and have narrowly defined the authority of the office. ${ }^{286}$ In these states, the attorney general may want to consider seeking express authorization from the state legislature. One of these states, Connecticut, passed such a law in 2011 giving the state attorney general express power to exercise concurrent powers under the Dodd-Frank Act. ${ }^{287}$

The power to enforce, however, may have no effect absent the power to investigate. As examined earlier, a few states such as California have given their state attorney general broad investigative powers by legislation. In most states, however, legislative authorization in the area of consumer protection is limited to investigations brought under the state UDAP. ${ }^{288}$ Although an attorney general may rely on common law powers where a state recognizes them, some state attorneys general may want to seek express authorization. The State of Washington provides perhaps the best example, granting power to investigate in connection with any exercise of power granted under federal law. ${ }^{289}$

\section{COOPERATION}

Most important, states in conversation with the CFPB need to build the infrastructure for partnerships. Fostering cooperation is important to achieve an efficient allocation of resources, provide predictability for industry, and prevent over-enforcement. ${ }^{20}$ Moreover, enforcement is not

285 . See supra note 200 and accompanying text.

286. See supra note 200 and accompanying text.

287. Act of July 1, 2011 , 2011 Conn. Legis. Serv. P.A. 11-119 (codified at CONN. GEN. STAT. $\$ 3$-129e) ("The Attorney General may bring a civil action in any court of competent jurisdiction to enforce any provision of the Dodd-Frank Wall Street Reform and Consumer Protection Act, Public Law $111-203$, that a state attomey general is authorized by said act to enforce and to seek any relief that a state attorney general is authorized by said act to seek.").

288. See supra notes $191-92$ and accompanying text.

289. See supra note 205 .

29o. See Lemos, supra note 4 , at 703 . 
the only tool to ensure compliance. The CFPB and other federal regulators have supervisory powers over many entities. ${ }^{29}$ Supervision can often be a far more efficient means of compliance than enforcement, with the latter serving as a back-up strategy where supervision has failed or against the more egregious offenders. And yet without strong state-federal partnerships, state enforcement may cut short the supervisory process. These partnerships may be fragile or elusive, given competing political incentives and ideological differences. And by design, Congress empowered states to play an important role even when they lack a strong federal partner. ${ }^{292}$ But the system will work best when these partnerships flourish, in both formal and informal ways. Cooperation should extend to at least three areas: information systems, investigations and enforcement actions, and rulemaking.

\section{Information Systems}

Systems that collect and process complaints play a critical role in the work of state attorneys general, especially in the area of consumer protection. ${ }^{293}$ They provide a direct connection to consumers, facilitating informed decision-making about what to investigate and when to bring an enforcement action. Although the sophistication of these systems is widely divergent, both SAGs and The CFPB have them. ${ }^{294}$ These systems allow officials to collect, organize, distribute, analyze, and respond to information they receive. Each function presents opportunities to for states to partner with federal or other state actors.

Consumers of financial products and services have multiple channels to register their complaints, including with the state attorney general, the Better Business Bureau, and a new online system by the CFPB. Effectively organizing and sharing information collected through these systems promises to increase not only the quantity of information, but also its quality. Information about emerging regional or even national threats, for

\footnotetext{
291. See supra notes $74-77$ and accompanying text.

292. See Barkow, supra note 4 , at $5^{6-58}$.

293. See Cox, supra note 189 , at 86 .

294. STATE ATtORNEYS GENERAL, supra note 189, at 120, 238-39; Consumer Response: $A$ Snapshot of Complaints Received, Consumer Fin. PROT. BUREAU (June 19, 2012 ), http://files. consumerfinance.gov/f/201206_cfpb_shapshot_complaints-received.pdf; Kate Davidson, How Does the CFPB Complaint System Work?, AM. BANKER (Nov. 30, 2011, 5:05 PM), http://www. americanbanker.com/issues/176_231/cfpb-complaint-system-1044485-1.html; OFFICE OF INSPECTOR GEN., EVALUATION OF THE CONSUMER FINANCIAL PROTECTION BUREAU's CONSUMER RESPONSE UNIT (2012), available at http://www.federalreserve.gov/oig/files/Evaluation_CFPB_ CRU_September2012.pdf. Currently the CFPB receives complaints at http://www.consumer finance.gov/complaint related to mortgages, credit cards, bank accounts or services, vehicle or consumer loans, student loans, debt collections, money transfers, and credit reporting. CONSUMER FIN. PROT. BUREAU, http://www.consumerfinance.gov/complaint/ (last visited Sept. 20, 2013).
} 
example, may affect the type of state response or the state's judgment about the best actor to respond to the threat.

Title $\mathrm{X}$ addresses the issue of information-sharing by the CFPB with the states, in some instances requiring it and in others making it discretionary. The law requires the federal agency to share its complaints with the states. ${ }^{295}$ In addition, the statute requires the agency to share examination reports with the states, ${ }^{296}$ and gives it discretion to share "any other report or other confidential supervisory information," 297 although the agency has made clear it will not routinely share such information..$^{29}$ To qualify for information-sharing, the statute requires that states ensure confidentiality. ${ }^{299}$

The agency, a few states, and even one city3 ${ }^{\circ \circ}$ have already taken steps to share information. The CFPB has promulgated regulations governing the disclosure and use of confidential information shared with the states..$^{301}$ Moreover, the agency has signed MOUs with several states pledging to secure confidential information. ${ }^{\circ 2}$ The CFPB uses Consumer Sentinel Network as an online platform for sharing confidential complaint information with law enforcement officials at the state, local, and federal

295. In the section dealing with the collection and tracking of complaints in Title $\mathrm{X}$, Congress said that "State agencies may receive appropriate complaints." Dodd-Frank Wall Street Reform and Consumer Protection Act $\$ 1013$ (b)(3)(B), Pub. L. No. 11-203, 124 Stat. 2012 (2010) (emphasis added). The same sub-section, however, later states: "To facilitate preparation of the reports [for Congress], supervision and enforcement activities, and monitoring of the market for consumer financial products and services, the Bureau shall share consumer complaint information with ... State agencies." Id. $\S 1013$ (b)(3)(D) (emphasis added). The CFPB's regulations require the agency to share complaints with the states, 12 C.F.R. $\$ 1070.43$ (a)(2) (2012), and draft examination reports, 12 C.F.R. $\$ 1070.43$ (a) (1).

296. Dodd-Frank Act $\$ 1022$ (c)(6)(C)(i); 12 C.F.R. $\$ 1070.43$ (a) (1).

297. Dodd-Frank Act $\$ 1022$ (c) (6) (C) (ii); 12 C.F.R. $\$ 1070.43$ (b) (1).

298. CFPB Bulletin 12-oI, CONSUMER FIN. PROT. BUREAU (Jan. 4, 2012), http://files.consumerfinance.gov/f/2012/01/GC_bulletin_12-01.pdf. ("[T] he Bureau will not routinely share confidential supervisory information with agencies that are not engaged in supervision. Except where required by law, the Bureau's policy is to share confidential supervisory information with law enforcement agencies, including State Attorneys General, only in very limited circumstances and upon review of all the relevant facts and considerations.").

299. Dodd-Frank Act $\$ 1013$ (b) (3) (B) (iii).

3oo. Press Release, City of Chi., Office of the Mayor, Mayor Emanuel Announces New Reforms to Protect Chicago Families from Financial Fraud (Dec. 5, 2012), available at http://www.cityofchicago.org/content/dam/city/depts/mayor/Press\%2oRoom/Press\%2oRel eases/201 2/December/1 2.5.12FinancialFraud.pdf.

301. Disclosure of Records and Information, 76 Fed. Reg. 45,372, 45,394 (July 28, 2011) (codified at 12 C.F.R. $\$ \S 1070.40-47$ ).

302. See CFPB, MEMORANDUM OF UNDERSTANDING BETWEEN CFPB AND [STATE] (Mar. 2, 2012 ) (on file with the author); Carter Dougherty, Republican State AGs Resisting Cooperation with CFPB, BLOOMBERG (Sept. 19, 2012 ), available at http://www.bloomberg.com/news/201 2-o9$19 /$ republican-state-ags-resisting-cooperation-with-consumer-bureau.html. 
levels. ${ }^{303}$ Consumer Sentinel is a secure, online database maintained by the FTC that provides access to complaints shared not only with the FTC and the CFPB, but multiple other federal, state, and private organizations such as the Better Business Bureau. s $^{\circ}$ Nearly all SAG offices have access to the network,305 and eight states share their complaints on Sentinel. ${ }^{306}$

In addition to measures already enacted or underway, state attorney general offices need to take at least two further steps to bolster informationsharing. First, states need to do a thorough review of state publicinformation laws and ensure they can fulfill the confidentiality requirements established by the CFPB.307 Some states have robust freedom-of-information laws that could raise obstacles, particularly if the state receives the information outside the context of a particular investigation. ${ }^{\circ 08}$ Arguably the information should be safe because the federal government only shares under the condition of confidentiality, ${ }^{\circ 09}$ but a state court interpreting a law that has historically given citizens broad access to information may conclude otherwise. As a last measure, a state might consider amending its publicinformation laws to create an express exemption for information received from federal agencies for law-enforcement purposes. Although state FOIA laws generally include an exemption for "law enforcement purposes," the legislature would want to define the term to include pre-investigation activities..$^{10}$ Moreover, a state worried about creating too large an exemption might draw it narrowly to cover only complaints used by a state agency exercising its powers under Title $\mathrm{X}$.

303. Sartaj Alag, Consumer Response Now Sharing Complaints with FTC Consumer Sentinel, CONSUMER Fin. PROT. BUREAU Blog (Mar. 14, 2012), http://www.consumerfinance.gov/ blog/consumer-response-now-sharing-complaints-with-ftc-consumer-sentinel.

304. Consumer Sentinel Network Data Book, FED. TRADE COMM'N, http://www.ftc.gov/sentinel/ reports.shtml (last visited Sept. 20, 2013 ).

305. Sentinel Members List, FED. TRADE COMM'N, https://register.consumersentinel.gov/Agency/ AgencyLookup.aspx\#State (last visited Sept. 20, 2013).

306. Consumer Sentinel Network Data Contributors, FED. TRADE COMM'N, http://www.ftc.gov/ sentinel/datacontributors.shtml (last visited Sept. 20, 2013).

307. For a general overview of state public information laws, see JAMES T. O'REILLY, FEDERAL INFORMATION DISCLOSURE $\$ 27.1-23$ (3d ed. 2011 ).

308. See, e.g., FLA. CONST., Art. I, § 24 (access to public records and meetings); FLA. STAT. \$1 19.01-19; GA. CODE ANN. § 132-1 to 132.10 .

309. 12 C.F.R. $\$ 1070.43$ (b) (1)(v) (2012) (specifying that all state requests for information must include " $[\mathrm{a}]$ commitment that the [state] agency will maintain the requested confidential information in a manner that conforms to the standards that apply to federal agencies for the protection of the confidentiality of personally identifiable information and for data security and integrity").

310. See, e.g., Haynie v. Superior Court of L.A. Cnty., 95 Cal. Rptr. 2d 56o, 567 (Cal. Ct. App. May 2, 2000) ("[R]ecords created before or during the stop cannot be withheld under [the state FOIA law] because the prospect of enforcement proceedings were not concrete and definite when the records were prepared."), overruled by Haynie v. Superior Court of L.A. Cnty., 112 Cal.Rptr. 80 (Cal. 2011 ). 
Second, more state attorneys general should consider sharing their consumer complaints through Consumer Sentinel, as long as they can ensure confidentiality of consumers' personal information and any proprietary information as well. SAGs are closer to consumers than a distant federal agency, which can shape both the type and quantity of complaints they receive. Although scams are sometimes purely local, they often repeat or connect with events on a regional or national level. Many SAG offices lack the technical capacity to share complaints, and limited resources may prove prohibitive. Nonetheless, broader sharing of information will both allow SAGs to better carry out their consumer protection mission-for example, with real-time data of consumer fraud at their borders-and allow the CFPB and other federal agencies charged with protecting consumers to play a more informed, supportive role.

In addition to sharing information, the states and the CFPB can also partner to analyze and respond to consumer-complaint information in a manner that is more efficient and effective than would be possible through individual efforts alone. The federal agency's size and resources allow it to play an important supportive role, examining consumer complaints and providing sophisticated analysis. Moreover, in some cases consumers will contact the CFPB on a matter either better handled at the state level, or over which the agency lacks authority..$^{13}$ And in other cases the federal agency may be better positioned to respond to the complaint, and states should have protocols for making referrals as well.

By design, the states can play both a cooperative and competitive role under the Dodd-Frank dual-enforcement regime. Establishing robust information-sharing systems that protect confidential information should be a priority, especially at this moment. Every step by the CFPB has the potential to define the new agency well into the future. Putting these systems in place now, when the agency has expressly repeated its commitment to partnering with the states, will increase the likelihood that they will endure even if a future administration is less consumer-friendly.

\section{Investigation and Enforcement Actions}

The state-federal partnership should extend not only to building coordinated information systems, but also to coordinating investigations and enforcement actions. These relationships will have limits. The partners to this relationship are ultimately separate sovereigns who will make their own decisions regardless of the infrastructure for coordination that is in place. Ideology will pay some role, depending on both the particular state attorney general and leadership at the CFPB.312 Resource limits, especially by the states, will shape decision-making. And at a fundamental level the state and

311. See supra notes $79-80$ and accompanying text.

312. See supra note 271 and accompanying text. 
federal partners are very different kinds of actors, a difference which has implications for interactions between the two as well..$^{13}$

Nonetheless, coordinating actions within a concurrent-enforcement regime is not without precedent. Antitrust law is one example.314 Although the coordination that emerged in this context has limits and is defined by the different federal actors and substantive law, it suggests the possibility for complementarity between sometimes very different actors. State-federal coordination for investigation and enforcement has at least five benefits.

The first benefit is the scope of enforcement authority. If the broad reading of section $104^{2}$ is correct, $3^{35}$ then with only one exception-the enforcement of the UDAAP ban against federally chartered depositories ${ }^{16}$ state attorneys general have the widest authority of any actor to enforce federal consumer financial law. Against depositories, Title X limits the CFPB to enforcing federal consumer financial law only as to institutions with assets above a defined threshold.917 Enforcement against depositories below the threshold lies in the hands of the prudential regulator. ${ }^{318}$ In a situation where the prudential regulator refuses to act, the CFPB may be able to assist the states in bringing actions. ${ }^{319}$

A second benefit is jurisdiction. States are limited in their ability to reach across state lines, either to investigate or to bring enforcement actions.320 The CFPB has power to investigate, including issuing civil investigative demands that potentially reach both targets and non-targets

313. See Lemos, supra note 4 , at $717-36$.

314. See 15 U.S.C. $\$ 15^{\mathrm{c}}$ (2006). For analysis of state enforcement of federal antitrust law, see generally Stephen Calkins, Perspectives on State and Federal Antitrust Enforcement, 53 DUKE L.J. 673 (2003); Patricia A. Conners, Current Trends and Issues in State Antitrust Enforcement, 16 LoY. CONSUMER L. REV. 37 (2003); Harry First, Delivering Remedies: The Role of the States in Antitrust Enforcement, 69 GEO. WASH. L. REV. 1004 (2001); Michael S. Greve, Cartel Federalism? Antitrust Enforcement by State Attomeys General, 72 U. CHI. L. REV. 99 (2005); Stephen Paul Mahinka \& Kathleen M. Sanzo, Multistate Antitrust and Consumer Protection Investigations: Practical Concerns, 63 ANTITRUST L.J. 213 (1994); STATE ATTORNEYS GENERAL, supra note 189, at 271-91; Richard A. Posner, Federalism and the Enforcement of Antitrust Laws by State Attomeys General, in COMPETITION LAWS IN CONFLICT: ANTITRUST JURISDICTION IN THE GLOBAL ECONOMY 252 (Richard A. Epstein \& Michael S. Greve eds., 2004); Roger Slade, Federal Obstruction of State Antitrust Enforcement: The Second Circuit Finds No Place for State Participation in the Fast World of Mergers, 52 BROOK. L. REv. 591 (1986).

315. See supra notes $14^{\circ}-77^{\text {and }}$ accompanying text.

316. See supra notes 141 and accompanying text.

317. Dodd-Frank Wall Street Reform and Consumer Protection Act, Pub. L. No. 11-203, $\$ \S 1026(d)(1), 1026(a), 124$ Stat. 2012 (2010).

318. Id.

319. The limit on the CFPB's enforcement power based on the asset threshold does not seem to apply to the agency's power to investigate. See id. $\$ 105^{2}$ (c)(1) (giving power to issued civil investigative demands " $[w]$ henever the Bureau has reason to believe that any person may be in possession [of material] relevant to a violation" (emphasis added)).

320. See supra notes $217^{-2} 5$ and accompanying text. 
that states are unable to reach.321 States focused on a particular target or area of consumer protection might consider negotiating standing requests with the CFPB for such demand material. ${ }^{22}$ The same advantage pertains to enforcement actions. For example, the CFPB may have an important role to play in the enforcement of federal consumer financial law as it applies to internet payday lenders who ally with Indian tribes that enjoy tribal sovereign immunity and are therefore exempt from state consumer protection laws-a growing problem that has left state attorneys general with few options. ${ }^{323}$

A third benefit is the availability of expertise and other human resources. For example, building a strong case may require technical assistance that SAG offices lack, such as economists who can perform regression analysis or forensic accountants who can identify and trace fraudulent activities. A fourth benefit is knowledge of targets. States may have more local knowledge, whereas the CFPB may have a better understanding of practices that reach across a region or the nation. The final benefit is remedies. State attorneys general have a long history of recovering money for individual consumers whereas federal actors have often lacked this focus.324 Together, these factors may favor several arrangements: the state or the federal partner acting alone, one taking the lead with the other playing a supporting role, or the bringing of a joint investigation and even a joint enforcement action.

To facilitate these partnerships, the states and the CFPB should agree to a Protocol for Coordination. This protocol should borrow from a 1998 agreement in the field of antitrust between the state attorneys general, the U.S. Department of Justice, and the Federal Trade Commission. ${ }^{325}$ This agreement outlined a framework for how the states and the federal agencies would conduct joint or coordinated investigations and enforcement actions. The first two sections of the antitrust protocol covered confidential information, which in the consumer financial protection context is already covered by regulation ${ }^{326}$ and the MOU that the CFPB has been signing with

321. Dodd-Frank Act $§ 1052$ (c)(1).

322. See 12 C.F.R. $\S 1070.43$ (d) (2012).

323. See generally Nathalie Martin \& Joshua Schwartz, The Alliance Between Payday Lenders and Tribes: Are Both Tribal Sovereignty and Consumer Protection at Rish?, 69 WASH. \& LEE L. REV. $75^{1}$ (2012); Carter Dougherty, Payday Lenders and Indians Evading Laws Draw Scrutiny, BLOOMBERG (June 5, 2012), auailable at http://www.bloomberg.com/news/2012-06-o4/payday-lenders-andindian-tribes-evading-laws-draw-scrutiny-1-.html; Jessica Silver-Greenberg, Payday Lenders Join With Indian Tribes, WALL ST. J. (Feb. 10, 2011), available at http://online.wsj.com/article/

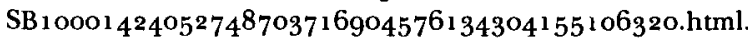

324. See supra notes $249-56$ and accompanying text.

325. See Protocol for Coordination in Merger Investigations between the Federal Enforcement Agencies and State Attomeys General (1998), in 1 WILllaM A. HANCOCK, MATERIALS ON ANTITRUST COMPLIANCE $\$ 15.3$ ( 3 d ed. 2007 \& Supp. 2012 ).

326. See supra notes $295-99$. 
individual states.327 The remaining three sections, however, provide a model for a similar agreement in the area of consumer financial protection. This agreement would cover coordination of strategic planning, such as assigning areas of responsibility and identifying theories of the case; coordination of document production; and coordination of interviewing and perhaps deposing witnesses. The agreement would also cover collaboration in the settlement process and the release of information to the public.328 The NAAG's Consumer Financial Protection Working Group should take the lead in negotiating a similar protocol with the CFPB, and perhaps other federal agencies charged with enforcing consumer financial protection law. 329

Lastly, state attorneys general should consult with the CFPB to test new theories interpreting the law, especially the UDAAP ban. Uniform application of federal consumer protection law and local experimentation both carry costs and benefits and neither goal should subsume the other. Ensuring open lines of communication between the states and the CFPB, while respecting the states' independent powers, is critical to preserve a productive tension between predictability and innovation. Although the provision requiring states to give notice to the CFPB before bringing an action under federal law is captioned "Consultation Required," $33^{\circ}$ the substantive requirements placed upon states are nothing more than a requirement to give notice. But the states should go further, engaging the CFPB to test their theories and to consider implications they may have overlooked. The CFPB has expressly invited the states to engage the agency in this manner.331 Outside this informal process, the CFPB also has limited formal means to circumscribe the power of states if it believes the value of predictability is threatened. The agency can intervene and remove enforcement actions to federal district court. ${ }^{322}$ And the CFPB can always

327. See supra note 302 and accompanying text.

328. See infra note 325 .

329. Although my focus has been on state-federal coordination of investigations and enforcement actions, the same coordination should develop among states. This coordination is critical for many of the same reasons that state-federal coordination is important. Additionally, for the first time the states have the power to enforce a uniform body of consumer financial protection laws, which could significantly lower the costs of coordinated action. The NAAG should seek to facilitate these partnerships.

33o. Dodd-Frank Wall Street Reform and Consumer Protection Act, Pub. L. No. 11-203, $\S 104^{2}$ (b), 124 Stat. 2012 (2010).

331. State Official Notification Rule, 77 Fed. Reg. 39112-01, 39113 (June 29, 2012) ("The Bureau, however, encourages State Officials and other Federal law enforcement agencies to consult with the Bureau regarding issues related to enforcement of Federal consumer financial law, especially the Dodd-Frank Act's prohibition on unfair, deceptive and abusive acts and practices. The Bureau will make resources available through its Office of Enforcement to provide consultation on such issues as needed, even if the action is not one for which the Bureau requires notification.").

332. Dodd-Frank Act $\$ 1042(b)(2)$. 
promulgate regulations under the open-ended UDAAP standard. Regulation, however, is not merely a means to limit the power of states; it can also augment state power, since the statute empowers states to enforce UDAAP regulations against federal depositories. 333

\section{Rulemaking}

A final avenue for coordination is rulemaking. Unique to federal administrative law, Title $\mathrm{X}$ includes a provision that requires the CFPB to issue a notice of proposed rulemaking when a majority of the states enact resolutions in support of a new rule. 334 Although the decision is ultimately in the hands of the CFPB, taking into account costs and benefits, implications for safety and soundness, and other concerns, 335 this provision gives the states considerable power to shape federal law, if only because of the public attention any such action would garner. State attorneys general, perhaps working through the National Association of Attorneys General, are in the best position to coordinate these efforts.

\section{IMPLICATIONS}

The enforcement power Congress gave the states under Title $\mathrm{X}$ has implications at several levels, including consumer finance and American federalism. My purpose here is limited. I do not offer a normative account, but rather identify key questions and offer a few preliminary observations about where such an account might go. I offer these observations as part of a nascent but important conversation that has emerged over the past few years about dual-enforcement schemes.336 This growing body of scholarship provides the foundation for a normative assessment of the role states play in federal consumer financial protection. At the same time, the dualenforcement scheme under Title $\mathrm{X}$ provides a rich source of materials for testing these ideas and advancing the conversation.

\section{A. CONSUMER FINANCE}

A normative assessment of Title X's system of dual-enforcement and its contribution to protecting consumers in the financial marketplace will need to consider two main questions. First, do the benefits outweigh the costs? And second, should Congress or the CFPB consider any regulatory modifications to maximize benefits and reduce costs?

333. See supra notes 100 and accompanying text.

334. Dodd-Frank Act $\$ 1041$ (c) (1).

335. Id. $§ 1041(\mathrm{c})(2)$.

336. See supra note 4. More recent scholarship on concurrent regulatory regimes has also contributed to this conversation. See, e.g., Jessica Bulman-Pozen, Federalism as a Safeguard of the Separation of Powers, 112 COLUM. L. REV. 459 (2012); Jessica Bulman-Pozen \& Heather K. Gerken, Uncooperative Federalism, 18 YALE L. J. 1256 (2009). 
The emerging body of scholarship on dual-enforcement regimes has produced a fairly consistent list of potential costs and benefits that can serve as reference points to measure success.337 Benefits include force multiplication, local knowledge, accountability, democratic participation, and innovation. At a basic level, empowering state attorneys general to enforce federal consumer financial protection law augments the number of enforcers. Moreover, these state actors bring to the table local knowledge that distant federal enforcers may lack. The last three benefits I discuss in the next Subpart.

At the same time, concurrent-enforcement regimes may also incur several costs, including over-enforcement, nonuniformity in federal law, federal policy distortion, and redundancy expenses. $3^{8}$ Although any enforcement scheme is vulnerable to over-enforcement, spreading this authority to fifty state actors who do not finally answer to the executive branch of the federal government heightens the risk. This multiplicity also introduces a greater chance of nonuniformity in federal law, increasing compliance costs. A federal agency with exclusive enforcement authority has much greater control over the interpretation of federal law. And lastly, the powers Congress gave the states under Title $\mathrm{X}$ have the potential to generate redundancy costs. State and federal government may bear these costs in the form of overlapping enforcement expenses and industry may bear them as expenses associated with monitoring and responding to multiple enforcers.

In measuring the success of the Dodd-Frank dual-enforcement scheme by applying these factors, future normative work should keep in mind three guiding principles. First, despite some of the political rhetoric surrounding the Dodd-Frank Act, Title X includes several safeguards to limit the exercise of state power, and Congress can employ other measures as well, if needed. These safeguards include the state's obligation to give notice before bringing an enforcement action;339 The CFPB's right of intervention and removal; $34^{\circ}$ the restriction on state's enforcing the statutory UDAAP ban against federal depositories;34' the CFPB's power to define UDAAP through regulation, $34^{2}$ possibly closing the door to broader applications championed by one or more states; and a limited but still extant power to preempt state law.343 In addition, while the office of state attorney general has several

337. See Barkow, supra note 4 , at 56-58; Bulman-Pozen \& Gerken, supra note $33^{6}$, at $128_{4}-$ 91 ; Lemos, supra note 4 , at 744-64; Rose, supra note 4 , at $9^{-16}$; Widman, supra note 4 , at $209-$ 14 ; Wilmarth, supra note 3 , at $94^{8-53}$.

338. See supra note 239.

339. Dodd-Frank Act $\S 10_{42}^{2}$ (b).

340. Id.

341. Id. $\S 1042(\mathrm{a})(2)$.

342. Id. $\S 1031(\mathrm{~b})$.

343. Id. $\S \S 1044^{-1046 .}$ 
inherent incentives to bring enforcement actions, it also has inherent restrictions such as limited resources. 344

As a second guiding principle, scholars and policymakers should keep in mind that measuring the effectiveness and efficiency of the states' enforcement role under Title $\mathrm{X}$ is complicated by the enactment of multiple reforms. This renders it difficult to isolate causation and assign praise or blame, and it requires careful attention to the ways in which these reforms interact with one another. As mentioned earlier, Congress employed at least three strategies to bolster consumer protection in the financial marketplace: institutional design, new substantive rules, and federalism-based strategies. 345

In terms of agency design, Congress consolidated powers previously dispersed among many agencies within the new CFPB, charged the new agency with the sole mission of protecting consumers, and preserved a steady stream of funding independent of Congressional whim and the choices of regulated entities. Congress also created new substantive norms for federal and state agencies to enforce, including the mortgage rules under Title XIV, and the broad UDAAP ban that vests significant discretion in the hands of enforcers to address evolving threats to consumers. Finally, Congress employed the forces of federalism: limiting agency preemption of state laws and empowering states to enforce federal law. The sheer scope of reforms under Title $\mathrm{X}$ complicates the task of assessing what works and what does not, but also provides rich opportunities to see how various strategies interact with one another.

As a third guiding principle, any future amendments to this dualenforcement scheme must rest upon solid analysis of how the states, the CFPB, and other federal agencies exercise their powers. $34^{6}$ Amanda Rose identifies several relevant factors, including the rationale for federal regulation, the breadth of any substantive prohibitions, the presence of safeguards limiting the role of states, the availability of parallel state regulatory power, and the character of enforcement by state and federal

344. For a discussion of how the office of state attorney general and its defining characteristics-especially in the vast majority of states that elect the officer-affect the quality of state enforcement see Lemos, supra note 4, at 717-35; Rose, supra note 4 , at 27-30; Widman, supra note 4 , at 212.

345. See generally Barkow, supra note 4 , at $72-78$ (summarizing various strategies).

346. See Lemos, supra note 4 , at 754 ("Striking the correct balance requires answering a series of context-specific empirical questions regarding the actual practices of state, federal, and private enforcers and the effects of enforcement on regulated entities."); Rose, supra note 4, at 8 ("The point to take away is that although contexts differ, a sophisticated analysis of a concurrent state-federal enforcement regime requires more than an ad hoc-and potentially biased-weighing of costs and benefits. Attention to the context-specific factors identified in this Article is critical to distinguishing, on a principled basis, the settings where concurrent state enforcement is likely to be beneficial and those where it is likely to be detrimental, or at least of questionable value."). 
actors.347 Each of these considerations is critical to weighing the costs and benefits of Title X's concurrent-enforcement regime. The CFPB is a new federal agency with no track record. How the agency exercises its enforcement powers, and cooperates or competes with the states, will necessarily shape any normative assessment of the states' role under Title $\mathrm{X}$. The states do have a track record in other areas, $34^{8}$ although the only empirical study in the consumer protection context suggests that states have been slow to employ these powers.349 Moreover, experiences in other dualenforcement schemes may not be predictive. Title $\mathrm{X}$ creates a vastly broader regime than anything prior in the area of consumer financial protection. Moreover, states have been active in this area in the past and have been restricted, in part, not by their own decisions but by agency preemption.

\section{B. FEDERALISM}

The implications of the Dodd-Frank dual-enforcement scheme extend not only to immediate concerns about whether these reforms produce the optimal level of consumer protection, but also to the broader role such regimes play in American federalism. The scale of this scheme in an area where state attorneys general have traditionally been active, its defining features, its relationship to others reforms, and the recent history of agency capture all render it an important case study.

As states begin to exercise their new powers under Title X, scholars will have opportunity to test and refine several recurrent claims about the role of concurrent-enforcement regimes in a federalist system. I briefly mention five such claims, before considering several new insights this regime may offer.

\section{Recurrent Claims}

The first and most frequent claim is that concurrent-enforcement regimes remedy under-enforcement by holding federal agencies accountable to enforce federal law or filling in gaps with state enforcement.350 This accountability may be critical to counter agency capture, but can also check agency inaction due to other circumstances such as resource-allocation decisions or simple bureaucratic delay. Concurrentenforcement powers position states as both cooperators and competitors: at times working with the federal agency to carry out Congress's ends, but other times exercising powers that an agency may refuse or fail to employ. Not only does a dual-enforcement system provide an additional layer of

347. Rose, supra note 4 , at $15-31$.

348. See supra notes $90-98$ and accompanying text. See also Widman \& Cox, supra note 4 , at $55-61$.

349. Widman \& Cox, supra note 4 , at 81-82.

350. See Barkow, supra note 4 , at 56-58; Lemos, supra note 4, at 702-o3; Rose, supra note 4 , at 13-14; Widman, supra note 4, at 213-14; Wilmarth, supra note 3 , at 949-50. 
enforcement if the federal agency neglects its duties, but the enforcement actions of even one state attorney general can also garner media attention and shine a public light on agency dereliction.

The concurrent powers created under Title $\mathrm{X}$ offer an important testing ground, both because of the scale of powers conferred and because of the recent experience of federal banking agencies arguably captured by the industries they regulate. Faced with aggressive state attorneys general does the agency exercise its intervention powers? Does the agency go further, promulgating rules to circumscribe the potential reach of the UDAAP ban in an attempt effectively to "preempt" state enforcement actions? In addition, the Title $\mathrm{X}$ scheme provides the opportunity to test fears about possible costs, such as over-enforcement and nonuniformity in federal law.

A second claim is that concurrent-enforcement regimes bolster democratic participation at the federal level. ${ }^{35^{1}}$ This dynamic is both more apparent and more discussed in the context of "cooperative federalism" schemes, where Congress gives the states regulatory power under broad statutory mandates. But this same dynamic can arise in the context of dualenforcement regimes as well. Even where Congress has placed rulemaking powers solely in the hands of a federal regulator, the power to enforce federal law opens up opportunities for state influence.

Concurrent-enforcement regimes potentially strengthen democratic participation in two ways. First, empowering states to enforce federal law allows state attorneys general to adjust the level of enforcement in a state by providing greater consumer protection. $.5^{2}$ Second, these schemes allow state attorneys general who are more directly connected to citizens (and most of whom are elected) the opportunity to shape law that is otherwise in the hands of unelected federal administrators. This dynamic is especially true where Congress has given states power to enforce a broad statutory prohibition, such as the UDAAP ban. Such standards vest considerable discretion and, as a consequence, policymaking authority, in the hands of the enforcer. Although courts have the ultimate say and at most a state attorney general would enjoy Skidmore deference, ${ }^{853}$ the ability to set a policy and argue for it in court is an opportunity to shape the meaning of federal law in the absence of agency rulemaking. Policy-setting by the states under a broad prohibition also has the potential to influence agencies in less formal ways by shedding light on the shortcomings of alternative interpretations or suggesting novel interpretations the federal agency may have not considered.

351. See Bulman-Pozen, supra note 336 , at $478-81$; Lemos, supra note 4 , at $74^{\circ}$.

352. See Lemos, supra note 4 , at $746-47$.

353. Skidmore v. Swift \& Co., 323 U.S. 134 (1944). 
A third and related claim is that dual-enforcement schemes strengthen federal separation of powers.354 State attorneys general create a new line of accountability for the executive branch vis-à-vis Congress, as they step in to argue that a federal agency is not following the will of Congress. Title X's UDAAP ban, and in particular its inclusion of "abusive" along with a statutory definition, is an obvious place where states might play this role.

In addition, a fourth claim is that dual-enforcement regimes harness the power of states as laboratories of democracy. Giving states regulatory power under a scheme of cooperative federalism is not the only means to encourage innovation: shared enforcement powers can produce a similar benefit, including new applications of the law, a focus on targets neglected by federal enforcers, or fashioning new remedies. The idea is that these systems can alter not only the quantity of enforcement, but its quality as well. This dynamic is due in part to differences between the actors: unelected federal administrators versus (usually) elected state attorneys general. As Adam Levitin has argued, many SAGs are "normative entrepreneurs" whose direct political accountability to the citizenry often creates incentives for innovation, given the political benefits of high-profile consumer-protection enforcement. 355

And finally, a fifth claim is that concurrent-enforcement regimes foster democratic participation and accountability at the state level by giving state attorneys general powers they may otherwise lack under state law. Lemos emphasizes the importance of dual-enforcement schemes in "breaking open the black box that represents 'the state' to reveal the diverse group of state actors within." ${ }_{55}^{6}$ These schemes, she argues, empower state actors who may represent different constituencies other than the state legislature or who are more responsive to their needs given the role of the office in responding to consumer complaints. 357 This result promotes democracy.

The effect of concurrent-enforcement regimes on state separation of powers, however, is a topic deserving more attention. $3^{8}$ As mentioned above, empowering state attorneys general to enforce federal law has the ability to strengthen federal separation of powers, holding the federal executive more accountable to the will of Congress. And yet at the same time, this arrangement has the potential to weaken separation of powers at the state level, giving the state attorney general powers the state legislature may have expressly denied the office. Under Title $X$, the state attorney general-a creation of state constitutional, statutory, and common law-now

354. See Bulman-Pozen, supra note 336, at 478-81, 486-92.

355. Adam J. Levitin, Hydraulic Regulation: Regulating Credit Markets Upstream, 26 YALE J. ON REG. 143, 199-200 (2009); see also Provost, supra note 271.

356. Lemos, supra note 4 , at 746 .

357. Id. at $745^{-48}$.

358. See generally Roderick M. Hills, Jr., Dissecting the State: The Use of Federal Law to Free State and Local Officials from State Legislatures' Control, 97 MICH. L. REv. 1201 (1999). 
has sweeping authority to exercise similar powers in the area of consumer financial protection because of an act of Congress. While a state legislature could pass a law denying the state attorney general authority to exercise these concurrent powers, this avenue may, as a practical matter, be closed. Although Lemos's argument in favor of this dynamic may prove persuasive, the matter is worthy of close attention.

\section{New Insights}

In addition to testing recurrent themes, the power Congress bestowed upon the states in the Dodd-Frank Act also brings to light several considerations that have not received much attention in the literature and deserve further exploration. First, Title $\mathrm{X}$ raises the question whether concurrent-enforcement regimes have the potential to foster indirect competition between federal agencies and thereby enhance accountability. The attention on accountability so far has focused on direct competition between the states and a single federal regulator. The regulatory structure created under Title $\mathrm{X}$, however, opens up the possibility for one federal agency to partner with one or more states to hold another federal agency accountable.

As mentioned earlier, Congress consolidated consumer financial protections powers in the CFPB, but not completely. In the case of federal depositories with less than $\$ 10$ billion in assets, the enforcement of federal consumer financial law by federal regulators remains exclusively within the domain of the prudential regulator.359 The CFPB enforcement power against federal depositories is limited to the largest actors. ${ }^{360}$ At the same time, except for the limitation on only enforcing CFPB regulations against federal depositories, state attorneys general enjoy broader jurisdiction to enforce federal consumer financial laws than any one federal agency..$^{36}$ Divergent commitment levels to consumer protection among federal agencies are easily conceivable, given measures to insulate the CFPB from political pressures and the manifold mission of the prudential regulators. The regulatory structure created under Title $\mathrm{X}$ opens a space for the CFPB to partner closely with one or more state attorneys general to bring enforcement actions and foster accountability where a prudential regulator fails to act for whatever reason.

Second, Title $\mathrm{X}$ gives scholars and policymakers the opportunity to assess whether empowering states to enforce federal law may foster greater accountability when paired with a collective state power to initiate rulemaking. Although the decision to issue a final regulation remains in the

359. Dodd-Frank Wall Street Reform and Consumer Protection Act, Pub. L. No. $11-203$, $\S 1026(d), 124$ Stat. 2012 (2010).

36o. Id. \$ 1025 (c).

361 . Id. $\$ 1042$. 
hands of the CFPB, the agency is required to issue a notice of proposed rulemaking whenever a majority of states enact a resolution in support of creating or modifying a consumer protection regulation. ${ }^{362}$ If the CFPB decides not to issue such a rule, the agency must publicly state its reasons. This mechanism is novel in administrative law and, like the dualenforcement regime, employs the forces of federalism to enhance accountability where an agency fails to exercise its regulatory power. Although it remains to be seen whether states exercise this power, it potentially serves an important function-witness the Federal Reserve's failure to stop the most egregious mortgage lending practices leading up to the 2008 crisis, despite having rulemaking power to do so.369 Given their focus on consumer protection issues, state attorneys general are obvious point persons to shepherd such resolutions through the state legislature, with the NAAG perhaps playing an organizing role..$^{64}$ Pairing this power to initiate federal rulemaking with concurrentenforcement powers may increase the incentives for state attorneys general to exercise the former, since SAGs would have direct power to enforce these rules across the landscape of consumer finance, including against federal depositories.

Third, this dual-enforcement regime provides an important testing ground for considering how federal agencies should expend their limited enforcement resources, given the ability of states to bring many of the same actions. Dodd-Frank is an especially useful scheme to explore this question because of the comprehensive nature of the statute and the breadth of state authority. Should the CFPB, and the other federal agencies with enforcement powers, partner with consumer-friendly state attorneys general to bolster their efforts? Or might the agencies concentrate more resources in those states where consumer financial protection does not have strong political support? The answer to these questions will depend in part on political will, which may often diverge between federal agencies, and also on the perceived deterrent value of specific enforcement actions which can have spillover effects across state borders. These questions have both normative and empirical dimensions which future research will want to explore.

Fourth, and finally, congressional reforms under the Dodd-Frank Act provide an opportunity to consider the effectiveness of a concurrentenforcement strategy when paired with a constrained preemption strategy, and the effect these strategies have on each other. As mentioned earlier, Congress adopted multiple strategies in Title $\mathrm{X}$ to reform the federal system of consumer financial protection. ${ }^{365}$ These two strategies both employ the

\footnotetext{
362. See supra note 334 and accompanying text.

363. See supra note $4^{2}$ and accompanying text.

364. See NAT'L ASS'N OF ATTORNEYS GEN., supra note 202, at 5 .

$3_{5}$. See supra Part I.
} 
forces of federalism in service of increasing consumer protection and agency accountability.

Congress's decision to limit, although not eliminate, agency preemption of state law is, in one respect, surprising. As Amy Widman has observed, a common compromise in Congress is to create dual-enforcement powers "in exchange for the absolute preemption of state laws." 366 Moreover, Elizabeth Warren and Oren Bar-Gill-in many ways the academic architects of Title $\mathrm{X}$-suggested in their seminal article that preemption in the area of consumer financial protection was appropriate. ${ }^{67}$ Although Warren became a strong proponent of state attorneys general playing a key role under the Dodd-Frank Act during her short tenure at the CFPB, ${ }^{68}$ her original proposal did not include any role for the states. Nonetheless, Congress not only endowed state attorneys general with enforcement power but also limited the ability of federal agencies to preempt state law, ensuring that federal law would serve as a floor but not a ceiling. ${ }^{369}$

Future research will want to pay close attention to the interplay between these two strategies. States have not yet rushed to pass new laws, but Congress only recently granted this power. State leaders may have not yet absorbed these changes, and a consumer-friendly CFPB under the Obama administration may lower incentives to pass legislation. A revival of state regulation could dampen a state's readiness to exercise its concurrentenforcement powers, as it might instead prefer to enforce its own laws without the safeguards included in Title X. If states opt for state regulatory power over enforcing federal law, then costs such as over-enforcement and nonuniformity could increase. On the other hand, adopting both federalism-based strategies may be strong medicine for a stubborn malady. Despite the Title $X$ reforms, the CFPB and the other agencies remain

366. Widman, supra note 4 , at 207.

367. Bar-Gill \& Warren, supra note 2, at 83 ("The erosion of state power in itself need not be problematic from a consumer protection perspective. In an era of interstate banking uniform regulation of consumer credit products at the federal level may well be more efficient than a litany of consumer protection rules that vary from state to state. The problem is not in the federal preemption; it is in the failure of federal law to offer a suitable alternative to the preempted state law."); id. at $9^{8}$ n.323 (rejecting a federalism strategy that reverses the trend toward preemption and restores state regulatory power, on the grounds that some states would not exercise their powers, some states would not have the resources, and it would lead to nonuniformity in federal law).

368. See, e.g., Carter Dougherty, Warren Deputizes 50 State Attorneys General in Bid to Regulate U.S. Banks, BLOOMBERG (Dec. 2, 2010), available at http://www.bloomberg.com/news/201012-02/elizabeth-warren-recruits-dodd-frank-enforcers-from-5o-states.html.

369. Dodd-Frank Wall Street Reform and Consumer Protection Act, Pub. L. No. 1 1-203, $\$ \S 1044-1046,124$ Stat. 2012 (2010). 
susceptible to capture and recourse to state regulatory power may serve as an alternative means of accountability. $37^{\circ}$

\section{CONCLUSION}

Empowering states to enforce federal law was only one of multiple strategies Congress employed in the wake of the Great Recession to protect consumers in the financial marketplace. Nonetheless, this strategy is critical. The decade preceding the economic crisis demonstrates that agency design matters. And yet no agency is immune from capture. The same decade also shows that substantive rules matter. And yet an unenforced rule has little value. The vital third leg of the consumer protection stool is states: as cooperative but also competitive co-enforcers.

The success of this dual-enforcement scheme, however, is far from certain. On paper it is promising. But how the states exercise these powers has the potential to help or harm. Enforcement in any real-world application is always discretionary. And state attorneys general are, at most, volunteers. While Congress can command federal agencies or induce state action through federal largesse, it lacks either mechanism in this instance to affect the actions of fifty state attorneys general representing fifty sovereigns.

For this reason, the steps from paper to practice are especially important. The principle contribution of this Article is to illuminate a path forward: placing Title X's concurrent-enforcement scheme in the context of recent history; interpreting the scope of state substantive, procedural, and remedial powers under federal and state law; identifying implementation priorities; and then charting a path for normative accounts assessing the implications of this scheme for consumer finance and American federalism.

370. For an argument in favor of both concurrent enforcement and constrained preemption, see Widman, supra note 4 , at $169 \mathrm{n.1} 7,215$. 